4

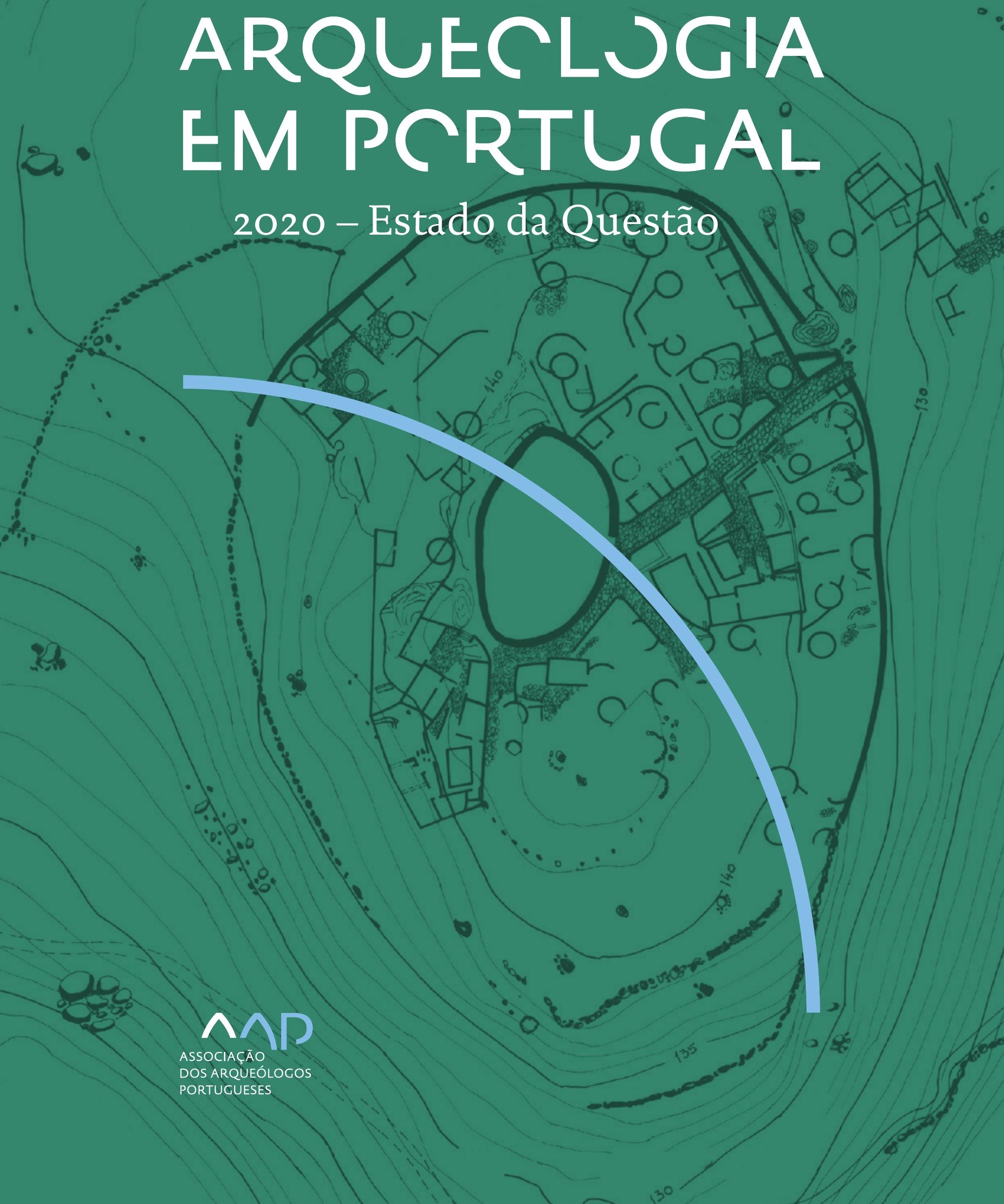


Coordenação editorial: José Morais Arnaud, César Neves e Andrea Martins Design gráfico: Flatland Design

AAP - ISBN: 978-972-9451-89-8

CITCEM - ISBN: 978-989-8970-25-1

Associação dos Arqueólogos Portugueses e CITCEM

Lisboa, 2020

O conteúdo dos artigos é da inteira responsabilidade dos autores. Sendo assim a Associação dos Arqueólogos Portugueses declina qualquer responsabilidade por eventuais equívocos ou questões de ordem ética e legal.

Desenho de capa:

Planta do castro de Monte Mozinho (Museu Municipal de Penafiel).

\section{$\hat{\wedge} \mathrm{P}$}

DOS ARQUEÓLOGOS PORTUGUESES

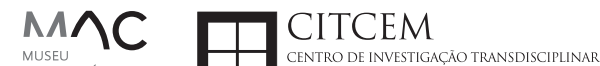
MUSEU
ARQUELLÓGICO
DO CARMO
U.PORTO

FLUP FACULDADE DE LETRAS
UNIVERSIDADE DO PORTO

Apoio

EC para a Ciência 


\section{Índice}

15 Prefácio

José Morais Arnaud

\section{Historiografia e Teoria}

17 Território, comunidade, memória e emoção: a contribuição da história da arqueologia (algumas primeiras e breves reflexões)

Ana Cristina Martins

25 Como descolonizar a arqueologia portuguesa?

Rui Gomes Coelho

41 Arqueologia e Modernidade: uma revisitação pessoal e breve de alguns aspetos da obra homónima de Julian Thomas de 2004

Vítor Oliveira Jorge

57 Dados para a História das Mulheres na Arqueologia portuguesa, dos finais do século XIX aos inícios do século XX: números, nomes e tabelas

Filipa Dimas / Mariana Diniz

73 Retractos da arqueologia portuguesa na imprensa: (in)visibilidades no feminino

Catarina Costeira / Elsa Luís

85 Arqueologia e Arqueólogos no Norte de Portugal Jacinta Bugalhão

101 Vieira Guimarães (1864-1939) e a arqueologia em Tomar: uma abordagem sobre o território e as gentes

João Amendoeira Peixoto / Ana Cristina Martins

115 Os memoráveis? A arqueologia algarvia na imprensa nacional e regional na presente centúria (2001-2019): características, visões do(s) passado(s) e a arqueologia

enquanto marca

Frederico Agosto / João Silva

129 A Evolução da Arqueologia Urbana e a Valorização Patrimonial no Barlavento Algarvio: Os casos de Portimão e Silves

Artur Mateus / Diogo Varandas / Rafael Boavida

\section{Gestão, Valorização e Salvaguarda do Património}

145 O Caderno Reivindicativo e as condições de trabalho em Arqueologia Miguel Rocha / Liliana Matias Carvalho / Regis Barbosa / Mauro Correia / Sara Simões / Jacinta Bugalhão / Sara Brito / Liliana Veríssimo Carvalho / Richard Peace / Pedro Peça / Cézer Santos

155 Os Estudos de Impacte Patrimonial como elemento para uma estratégia sustentável de minimização de impactes no âmbito de reconversões agrícolas Tiago do Pereiro

165 Salvaguarda de Património arqueológico em operações florestais: gestão e sensibilização Filipa Bragança / Gertrudes Zambujo / Sandra Lourenço / Belém Paiva / Carlos Banha / Frederico Tatá Regala / Helena Moura / Jacinta Bugalhão / João Marques / José Correia / Pedro Faria / Samuel Melro

179 Os valores do Património: uma investigação sobre os Sítios Pré-históricos de Arte Rupestre do Vale do Rio Côa e de Siega Verde José Paulo Francisco 
189 Conjugando recursos arqueológicos e naturais para potenciar as visitas ao Geoparque Litoral de Viana do Castelo (Noroeste de Portugal)

Hugo A. Sampaio / Ana M.S. Bettencourt / Susana Marinho / Ricardo Carvalhido

203 Áreas de Potencial Arqueológico na Região do Médio Tejo: Modelo Espacial Preditivo Rita Ferreira Anastácio / Ana Filipa Martins / Luiz Oosterbeek

223 Património Arqueológico e Gestão Territorial: O contributo da Arqueologia para a revisão do PDM de Avis

Ana Cristina Ribeiro

237 A coleção arqueológica do extinto Museu Municipal do Porto - Origens, Percursos e Estudos

Sónia Couto

251 Valpaços - uma nova carta arqueológica

Pedro Pereira / Maria de Fátima Casares Machado

263 Arqueologia na Cidade de Peniche

Adriano Constantino / Luís Rendeiro

273 Arqueologia Urbana: a cidade de Lagos como caso de Estudo Cátia Neto

285 Estratégias de promoção do património cultural subaquático nos Açores. O caso da ilha do Faial

José Luís Neto / José Bettencourt / Luís Borges / Pedro Parreira

297 Carta Arqueológica da Cidade Velha: Uma primeira abordagem

Jaylson Monteiro / Nireide Tavares / Sara da Veiga / Claudino Ramos / Edson Brito /

Carlos Carvalho / Francisco Moreira / Adalberto Tavares

311 Antropologia Virtual: novas metodologias para a análise morfológica e funcional Ricardo Miguel Godinho / Célia Gonçalves

\section{Didáctica da Arqueologia}

327 Como os projetos de Arqueologia podem contribuir para uma comunidade culturalmente mais consciente Alexandra Figueiredo / Claúdio Monteiro / Adolfo Silveira / Ricardo Lopes

337 Educação Patrimonial - Um cidadão esclarecido é um cidadão ativo! Ana Paula Almeida

351 A aproximação da Arqueologia à sala de aula: um caso de estudo no $3^{\circ}$ ciclo do Ensino Básico Luís Serrão Gil

363 Arqueologia 3.o - Pensar e comunicar a Arqueologia para um futuro sustentável Mónica Rolo

377 “Conversa de Arqueólogos" - Divulgar a Arqueologia em tempos de Pandemia Diogo Teixeira Dias

389 Escola Profissional de Arqueologia: desafios e oportunidades Susana Nunes / Dulcineia Pinto / Júlia Silva / Ana Mascarenhas

399 Os Museus de Arqueologia e os Jovens: a oferta educativa para o público adolescente Beatriz Correia Barata / Leonor Medeiros

411 O museu universitário como mediador entre a ciência e a sociedade: o exemplo da secção de arqueologia no Museu de História Natural e da Ciência da Universidade do Porto (MHNC-UP)

Rita Gaspar 
421 Museu de Lanifícios: Real Fábrica de Panos. Atividades no âmbito da Arqueologia Beatriz Correia Barata / Rita Salvado

427 Arqueologia Pública e o caso da localidade da Mata (Torres Novas) Cláudia Manso / Ana Rita Ferreira / Cristiana Ferreira / Vanessa Cardoso Antunes

431 Do sítio arqueológico ao museu: um percurso (também) didático Lídia Fernandes

447 Estão todos convidados para a Festa! E para dançar também... O projecto do Serviço Educativo do Museu Arqueológico do Carmo na $5^{\underline{a}}$ Edição da Festa da Arqueologia Rita Pires dos Santos

459 O “Clã de Carenque”, um projeto didático de arqueologia Eduardo Gonzalez Rocha

469 Mediação cultural: peixe que puxa carroça nas Ruínas Romanas de Troia Inês Vaz Pinto / Ana Patrícia Magalhães / Patrícia Brum / Filipa Santos

481 Didática Arqueológica, experiências do Projeto Mértola Vila Museu Maria de Fátima Palma / Clara Rodrigues / Susana Gómez / Lígia Rafael

\section{Arte Rupestre}

497 Os inventários de arte rupestre em Portugal Mila Simões de Abreu

513 O projeto FIRST-ART - conservação, documentação e gestão das primeiras manifestações de arte rupestre no Sudoeste da Península Ibérica: as grutas do Escoural e Maltravieso Sara Garcês / Hipólito Collado / José Julio García Arranz / Luiz Oosterbeek / António Carlos Silva / Pierluigi Rosina / Hugo Gomes / Anabela Borralheiro Pereira / George Nash / Esmeralda Gomes / Nelson Almeida / Carlos Carpetudo

523 Trabalhos de documentação de arte paleolítica realizados no âmbito do projeto PalæoCôa André Tomás Santos / António Fernando Barbosa / Luís Luís / Marcelo Silvestre / Thierry Aubry

537 Imagens fantasmagóricas, silhuetas elusivas: as figuras humanas na arte do Paleolítico Superior da região do Côa Mário Reis

$55^{1}$ Os motivos zoomórficos representados nas placas de tear de Vila Nova de São Pedro (Azambuja, Portugal) Andrea Martins / César Neves / José M. Arnaud / Mariana Diniz

571 Arte Rupestre do Monte de Góios (Lanhelas, Caminha). Síntese dos resultados dos trabalhos efectuados em 2007-2009 Mário Varela Gomes

599 Gravuras rupestres de barquiformes no Monte de S. Romão, Guimarães, Noroeste de Portugal Daniela Cardoso

613 Círculos segmentados gravados na Bacia do Rio Lima (Noroeste de Portugal): contributos para o seu estudo Diogo Marinho / Ana M.S. Bettencourt / Hugo Aluai Sampaio

631 Equídeos gravados no curso inferior do Rio Mouro, Monção (NW Portugal). Análise preliminar Coutinho, L.M. / Bettencourt, A.M.S / Sampaio, Hugo A.S

645 Paletas na Arte Rupestre do Noroeste de Portugal. Inventário preliminar Bruna Sousa Afonso / Ana M. S. Bettencourt / Hugo A. Sampaio 


\section{Pré-História}

661 O projeto Miño/Minho: balanço de quatro anos de trabalhos arqueológicos Sérgio Monteiro-Rodrigues / João Pedro Cunha-Ribeiro / Eduardo Méndez-Quintas / Carlos Ferreira / Pedro Xavier / José Meireles / Alberto Gomes / Manuel Santonja / Alfredo Pérez-González

677 A ocupação paleolítica da margem esquerda do Baixo Minho: a indústria lítica do sítio de Pedreiras 2 (Monção, Portugal) e a sua integração no contexto regional Carlos Ferreira / João Pedro Cunha-Ribeiro / Sérgio Monteiro-Rodrigues / Eduardo Méndez-Quintas / Pedro Xavier / José Meireles / Alberto Gomes / Manuel Santonja / Alfredo Pérez-González

693 O sítio acheulense do Plistocénico médio da Gruta da Aroeira Joan Daura / Montserrat Sanz / Filipa Rodrigues / Pedro Souto / João Zilhão

703 As sociedades neandertais no Barlavento algarvio: modelos preditivos com recurso aos SIG

Daniela Maio

715 A utilização de quartzo durante o Paleolítico Superior no território dos vales dos rios Vouga e Côa

Cristina Gameiro / Thierry Aubry / Bárbara Costa / Sérgio Gomes / Luís Luís / Carmen Manzano / André Tomás Santos

733 Uma perspetiva diacrónica da ocupação do concheiro do Cabeço da Amoreira (Muge, Portugal) a partir da tecnologia lítica Joana Belmiro / João Cascalheira / Célia Gonçalves

745 Novos dados sobre a Pré-história Antiga no concelho de Palmela. A intervenção arqueológica no sítio do Poceirão I

Michelle Teixeira Santos

757 Problemas em torno de Datas Absolutas Pré-Históricas no Norte do Alentejo Jorge de Oliveira

771 Povoamento pré-histórico nas áreas montanhosas do NO de Portugal: o Abrigo 1 de Vale de Cerdeira Pedro Xavier / José Meireles / Carlos Alves

783 Apreciação do povoamento do Neolítico Inicial na Baixa Bacia do Douro. A Lavra I (Serra da Aboboreira) como caso de estudo Maria de Jesus Sanches

797 O Processo de Neolitização na Plataforma do Mondego: os dados do Sector C do Outeiro dos Castelos de Beijós (Carregal do Sal)

João Carlos de Senna-Martinez / José Manuel Quintã Ventura / Andreia Carvalho / Cíntia Maurício

823 Novos trabalhos na Lapa da Bugalheira (Almonda, Torres Novas) Filipa Rodrigues / Pedro Souto / Artur Ferreira / Alexandre Varanda / Luís Gomes / Helena Gomes / João Zilhão

837 A pedra polida e afeiçoada do sítio do Neolítico médio da Moita do Ourives (Benavente, Portugal)

César Neves

857 Casal do Outeiro (Encarnação, Mafra): novos contributos para o conhecimento do povoamento do Neolítico final na Península de Lisboa.

Cátia Delicado / Carlos Maneira e Costa / Marta Miranda / Ana Catarina Sousa

873 Stresse infantil, morbilidade e mortalidade no sítio arqueológico do Neolítico Final/ Calcolítico ( $4^{\circ}$ e $3^{\circ}$ milénio a.C.) do Monte do Carrascal 2 (Ferreira do Alentejo, Beja) Liliana Matias de Carvalho / Sofia N. Wasterlain 
885 Come together: O Conjunto Megalítico das Motas (Monção, Viana do Castelo) e as expressões Campaniformes do Alto Minho Ana Catarina Basílio / Rui Ramos

899 Trabalhos arqueológicos no sítio Calcolítico da Pedreira do Poio Carla Magalhães / João Muralha / Mário Reis / António Batarda Fernandes

913 O sítio arqueológico de Castanheiro do Vento. Da arquitectura do sítio à arquitectura de um território João Muralha Cardoso

925 Estudo zooarqueológico das faunas do Calcolítico final de Vila Nova de São Pedro (Azambuja, Portugal): Campanhas de 2017 e 2018 Cleia Detry / Ana Catarina Francisco / Mariana Diniz / Andrea Martins / César Neves / José Morais Arnaud

943 As faunas depositadas no Museu Arqueológico do Carmo provenientes de Vila Nova de São Pedro (Azambuja): as campanhas de 1937 a 1967 Ana Catarina Francisco / Cleia Detry / César Neves / Andrea Martins / Mariana Diniz / José Morais Arnaud

959 Análise funcional de material lítico em sílex do castro de Vila Nova de S. Pedro (Azambuja, Portugal): uma primeira abordagem Rafael Lima

971 O recinto da Folha do Ouro 1 (Serpa) no contexto dos recintos de fossos calcolíticos alentejanos

António Carlos Valera / Tiago do Pereiro / Pedro Valério / António M. Monge Soares

\section{Proto-História}

987 Produção de sal marinho na Idade do Bronze do noroeste Português. Alguns dados para uma reflexão

Ana M. S. Bettencourt / Sara Luz / Nuno Oliveira / Pedro P. Simões / Maria Isabel C. Alves / Emílio Abad-Vidal

1001 A estátua-menir do Pedrão ou de São Bartolomeu do Mar (Esposende, noroeste de Portugal) no contexto arqueológico da fachada costeira de entre os rios Neiva e Cávado Ana M. S. Bettencourt / Manuel Santos-Estévez / Pedro Pimenta Simões / Luís Gonçalves

1015 O Castro do Muro (Vandoma/Baltar, Paredes) - notas para uma biografia de ocupação da Idade do Bronze à Idade Média

Maria Antónia D. Silva / Ana M. S. Bettencourt / António Manuel S. P. Silva / Natália Félix

1031 Do Bronze Final à Idade Média - continuidades e hiatos na ocupação de Povoados em Oliveira de Azeméis João Tiago Tavares / Adriaan de Man

1041 As faunas do final da Idade do Bronze no Sul de Portugal: leituras desde o Outeiro do Circo (Beja)

Nelson J. Almeida / Íris Dias / Cleia Detry / Eduardo Porfírio / Miguel Serra

1055 A Espada do Monte das Oliveiras (Serpa) - uma arma do Bronze Pleno do Sudoeste Rui M. G. Monge Soares / Pedro Valério / Mariana Nabais / António M. Monge Soares

1065 São Julião da Branca (Albergaria-a-Velha) - Investigação e valorização de um povoado do Bronze Final

António Manuel S. P. Silva / Paulo A. P. Lemos / Sara Almeida e Silva / Edite Martins de Sá

1083 Do castro de S. João ao Mosteiro de Santa Clara: notícia de uma intervenção arqueológica, em Vila do Conde Rui Pinheiro 
1095 O castro de Ovil (Espinho), um quarto de século de investigação - resultados e questões em aberto

Jorge Fernando Salvador / António Manuel S. P. Silva

1111 O Castro de Salreu (Estarreja), um povoado proto-histórico no litoral do Entre Douro e Vouga

Sara Almeida e Silva / António Manuel S. P. Silva / Paulo A. P. Lemos / Edite Martins de Sá

1127 Castro de Nossa Senhora das Necessidades (Sernancelhe): uma primeira análise artefactual Telma Susana O. Ribeiro

${ }_{1141}$ A cividade de Bagunte. O estado atual da investigação Pedro Brochado de Almeida

1153 Zoomorfos na cerâmica da Idade do Ferro no NW Peninsular: inventário, cronologias e significado Nuno Oliveira / Cristina Seoane

1163 Vasos gregos em Portugal: diferentes maneiras de contar a história do intercâmbio cultural na Idade do Ferro

Daniela Ferreira

1175 Os exotica da necrópole da Idade do Ferro do Olival do Senhor dos Mártires (Alcácer do Sal) no seu contexto regional

Francisco B. Gomes

\section{Antiguidade Clássica e Tardia}

1191 O uso de madeira como combustível no sítio da Quinta de Crestelos (Baixo Sabor): da Idade do Ferro à Romanização Filipe Vaz / João Tereso / Sérgio Simões Pereira / José Sastre / Javier Larrazabal Galarza / Susana Cosme / José António Pereira / Israel Espi

1207 Cultivos de Época Romana no Baixo Sabor: continuidade em tempos de mudança? João Pedro Tereso / Sérgio Simões Pereira / Filipe Santos / Luís Seabra / Filipe Vaz

1221 A casa romana na Hispânia: aplicação dos modelos itálicos nas províncias ibéricas Fernanda Magalhães / Diego Machado / Manuela Martins

1235 As pinturas murais romanas da Rua General Sousa Machado, n. ${ }^{5}$ 1, Chaves José Carvalho

1243 Trás do Castelo (Vale de Mir, Pegarinhos, Alijó) - Uma exploração agrícola romana do Douro

Tony Silvino / Pedro Pereira

1255 A sequência de ocupação no quadrante sudeste de Bracara Augusta: as transformações de uma unidade doméstica Lara Fernandes / Manuela Martins

1263 Os Mosaicos com decoração geométrica e geométrico-vegetalista dos sítios arqueológicos da área do Conuentus Bracaraugustanus. Novas abordagens quanto à conservação, restauro, decoração e datação Maria de Fátima Abraços / Licínia Wrench

1277 “Casa Romana” do Castro de São Domingos (Cristelos, Lousada): Escavação, Estudo e Musealização Paulo André de P. Lemos

1291 A arqueobotânica no Castro de Guifões (Matosinhos, Noroeste de Portugal): O primeiro estudo carpológico

Luís Seabra / Andreia Arezes / Catarina Magalhães / José Varela / João Pedro Tereso 
1305 Um Horreum Augustano na Foz do Douro (Monte do Castelo de Gaia, Vila Nova de Gaia) Rui Ramos

1311 Ponderais romanos na Lusitânia: padrões, formas, materiais e contextos de utilização Diego Barrios Rodríguez

1323 Um almofariz centro-itálico na foz do Mondego

Marco Penajoia

1335 Estruturas romanas de Carnide - Lisboa Luísa Batalha / Mário Monteiro / Guilherme Cardoso

1347 O contexto funerário do sector da "necrópole NO" da Rua das Portas de S. Antão (Lisboa): o espaço, os artefactos, os indivíduos e a sua interconectividade na interpretação do passado Sílvia Loja, José Carlos Quaresma, Nelson Cabaço, Marina Lourenço, Sílvia Casimiro, Rodrigo Banha da Silva, Francisca Alves-Cardoso

${ }_{1361}$ Povoamento em época Romana na Amadora - resultados de um projeto pluridisciplinar Gisela Encarnação / Vanessa Dias

1371 A Arquitectura Residencial em Mirobriga (Santiago do Cacém): contributo a partir de um estudo de caso Filipe Sousa / Catarina Felício

${ }_{1385}$ O fim do ciclo. Saneamento e gestão de resíduos nos edifícios termais de Mirobriga (Santiago do Cacém)

Catarina Felício / Filipe Sousa

1399 Balsa, Topografia e Urbanismo de uma Cidade Portuária Vítor Silva Dias / João Pedro Bernardes / Celso Candeias / Cristina Tété Garcia

1413 No Largo das Mouras Velhas em Faro (2017): novas evidências da necrópole norte de Ossonoba e da sua ocupação medieval Ricardo Costeira da Silva / Paulo Botelho / Fernando Santos / Liliana Nunes

1429 Instrumentos de pesca recuperados numa fábrica de salga em Ossonoba (Faro) Inês Rasteiro / Ricardo Costeira da Silva / Paulo Botelho

1439 A Necrópole Romana do Eirô, Duas Igrejas (Penafiel): intervenção arqueológica de 2016 Laura Sousa / Teresa Soeiro

1457 Ritual, descarte ou afetividade? A presença de Canis lupus familiaris na Necrópole Noroeste de Olisipo (Lisboa)

Beatriz Calapez Santos / Sofia Simões Pereira / Rodrigo Banha da Silva / Sílvia Casimiro / Cleia Detry / Francisca Alves Cardoso

1467 Dinâmicas económicas em Bracara na Antiguidade Tardia Diego Machado / Manuela Martins / Fernanda Magalhães / Natália Botica

1479 Cerâmicas e Vidros da Antiguidade Tardia do Edifício sob a Igreja do Bom Jesus (Vila Nova de Gaia) Joaquim Filipe Ramos

1493 Novos contributos para a topografia histórica de Mértola no período romano e na Antiguidade Tardia Virgílio Lopes

\section{8. Época Medieval}

1511 Cerâmicas islâmicas no Garb setentrional "português": algumas evidências e incógnitas Constança dos Santos / Helena Catarino / Susana Gómez / Maria José Gonçalves / Isabel Inácio / Gonçalo Lopes / Jacinta Bugalhão / Sandra Cavaco / Jaquelina Covaneiro / Isabel Cristina Fernandes / Ana Sofia Gomes 
1525 Contributo para o conhecimento da cosmética islâmica, em Silves, durante a Idade Média Rosa Varela Gomes

1537 Yábura e o seu território - uma análise histórico-arqueológica de Évora entre os séculos VIII-XII José Rui Santos

1547 A encosta sul do Castelo de Palmela - resultados preliminares da escavação arqueológica Luís Filipe Pereira / Michelle Teixeira Santos

1559 A igreja de São Lourenço (Mouraria, Lisboa): um conjunto de silos e de cerâmica medieval islâmica

Andreia Filipa Moreira Rodrigues

1571 O registo material de movimentações populacionais no Médio Tejo, durante os séculos XII-XIII. Dois casos de "sunken featured buildings", nos concelhos de Cartaxo e Torres Novas Marco Liberato / Helena Santos / Nuno Santos

1585 O nordeste transmontano nos alvores da Idade média. Notas para reflexão Ana Maria da Costa Oliveira

1601 Sepulturas escavadas na rocha do Norte de Portugal e do Vale do Douro: primeiros resultados do Projecto SER-NPVD

Mário Jorge Barroca / César Guedes / Andreia Arezes / Ana Maria Oliveira

1619 "Portucalem Castrum Novum" entre o Mediterrâneo e o Atlântico: o estudo dos materiais cerâmicos alto-medievais do arqueossítio da rua de D. Hugo, nํ. 5 (Porto) João Luís Veloso

1627 A Alta Idade Média na fronteira de Lafões: notas preliminares sobre a Arqueologia no Concelho de Vouzela

Manuel Luís Real / Catarina Tente

1641 Um conjunto cerâmico medieval fora de portas: um breve testemunho aveirense Susana Temudo

${ }_{1651}$ Os Lóios do Porto: uma perspetiva integrada no panorama funerário da Baixa Idade Média à Época Moderna em meios urbanos em Portugal

Ana Lema Seabra

1659 O Caminho Português Interior de Santiago como eixo viário na Idade Média Pedro Azevedo

1665 Morfologia Urbana: Um exercício em torno do Castelo de Ourém André Donas-Botto / Jaqueline Pereira

1677 Intervenção arqueológica na Rua Marquês de Pombal/Largo do Espírito Santo (Bucelas, Loures)

Florbela Estêvão / Nathalie Antunes-Ferreira / Dário Ramos Neves / Inês Lisboa

1691 O Cemitério Medieval do Poço do Borratém e a espacialidade funerária na cidade de Lisboa Inês Belém / Vanessa Filipe / Vasco Noronha Vieira / Sónia Ferro / Rodrigo Banha da Silva

1705 Um Espaço Funerário Conventual do séc. XV em Lisboa: o caso do Convento de São Domingos da Cidade Sérgio Pedroso / Sílvia Casimiro / Rodrigo Banha da Silva / Francisca Alves Cardoso

\section{9. Época Moderna e Contemporânea}

1721 Arqueologia Moderna em Portugal: algumas reflexões críticas em torno da quantificação de conjuntos cerâmicos e suas inferências históricas e antropológicas Rodrigo Banha da Silva / André Bargão / Sara da Cruz Ferreira

1733 Faianças de dois contextos entre os finais do século XVI e XVIII do Palácio dos Condes de Penafiel, Lisboa

Martim Lopes / Tomás Mesquita 
1747 Um perfil de consumo do século XVIII na foz do Tejo: O caso do Mercado da Ribeira, Lisboa Sara da Cruz Ferreira / Rodrigo Banha da Silva / André Bargão

1761 Os Cachimbos dos Séculos XVII e XVIII do Palácio Mesquitela e Convento dos Inglesinhos (Lisboa)

Inês Simão / Marina Pinto / João Pimenta / Sara da Cruz Ferreira / André Bargão / Rodrigo Banha da Silva

1775 "Tomar os fumos da erua que chamão em Portugal erua sancta». Estudo de Cachimbos provenientes da Rua do Terreiro do Trigo, Lisboa

Miguel Martins de Sousa / José Pedro Henriques / Vanessa Galiza Filipe

1787 Cachimbos de Barro Caulínitico da Sé da Cidade Velha (República de Cabo Verde)

Rodrigo Banha da Silva / João Pimenta / Clementino Amaro

1801 Algumas considerações sobre espólio não cerâmico recuperado no Largo de Jesus (Lisboa) Carlos Boavida

1815 Adereços de vidro, dos séculos XVI-XVIII, procedentes do antigo Convento de Santana de Lisboa (anéis, braceletes e contas)

Joana Gonçalves / Rosa Varela Gomes / Mário Varela Gomes

1837 Da ostentação, luxo e poder à simplicidade do uso quotidiano: arqueologia e simbologia de joias e adornos da Idade Moderna Portuguesa Jéssica Iglésias

1849 Os amuletos em Portugal - dos objetos às superstições: o coral vermelho Alexandra Vieira

1865 Cerâmicas de Vila Franca de Xira nos séculos XV e XVI Eva Pires

1879 «Não passa por teu o que me pertence». Marcas de individualização associadas a faianças do Convento de Nossa Senhora de Aracoeli, Alcácer do Sal Catarina Parreira / Íris Fragoso / Miguel Martins de Sousa

1891 Cerâmica de Leiria: alguns focos de produção

Jaqueline Pereira / André Donas-Botto

1901 Os Fornos na Rua da Biquinha, em Óbidos Hugo Silva / Filipe Oliveira

1909 A casa de Pêro Fernandes, contador dos contos de D. Manuel I: o sítio arqueológico da Silha do Alferes, Seixal (século XVI) Mariana Nunes Ferreira

1921 O Alto da Vigia (Sintra) e a vigilância e defesa da costa Alexandre Gonçalves / Sandra Santos

1937 O contexto da torre sineira da Igreja de Santa Maria de Loures Paulo Calaveira / Martim Lopes

1949 A Necrópole do Hospital Militar do Castelo de São Jorge e as práticas funerárias na Lisboa de Época Moderna Susana Henriques / Liliana Matias de Carvalho / Ana Amarante / Sofia N. Wasterlain

1963 SAND - Sarilhos Grandes Entre dois Mundos: o adro da Igreja e a Paleobiologia dos ossos humanos recuperados

Paula Alves Pereira / Roger Lee Jesus / Bruno M. Magalhães

1975 Expansão urbana da vila de Cascais no século XVII e XVIII: a intervenção arqueológica na Rua da Vitória no 15 a 17

Tiago Pereira / Vanessa Filipe

1987 Novos dados para o conhecimento do Urbanismo de Faro em época Moderna Ana Rosa 
1995 Um exemplo de Arqueologia Urbana em Alcoutim: o Antigo Edifício dos CTT Marco Fernandes / Marta Dias / Alexandra Gradim / Virgílio Lopes / Susana Gómez Martínez

2007 Palácio dos Ferrazes (Rua das Flores/Rua da Vitória, Porto): a cocheira de Domingos Oliveira Maia

Francisco Raimundo

2021 As muitas vidas de um edifício urbano: História, Arqueologia e Antropologia no antigo Recreatório Paroquial de Penafiel Helena Bernardo / Jorge Sampaio / Marta Borges

2035 O convento de Nossa Senhora da Esperança de Ponta Delgada: o contributo da arqueologia para o conhecimento de um monumento identitário João Gonçalves Araújo / N’Zinga Oliveira

2047 Arqueologia na ilha do Corvo... em busca da capela de Nossa Senhora do Rosário Tânia Manuel Casimiro / José Luís Neto / Luís Borges / Pedro Parreira

2059 Perdidos à vista da Costa. Trabalhos arqueológicos subaquáticos na Barra do Tejo Jorge Freire / José Bettencourt / Augusto Salgado

2071 Arqueologia marítima em Cabo Verde: enquadramento e primeiros resultados do projecto CONCHA

José Bettencourt / Adilson Dias / Carlos Lima / Christelle Chouzenoux / Cristóvão Fonseca / Dúnia Pereira / Gonçalo Lopes / Inês Coelho / Jaylson Monteiro / José Lima / Maria Eugénia Alves / Patrícia Carvalho / Tiago Silva

2085 Trabalhos arqueológicos na Cidade Velha (Ribeira Grande de Santiago, Cabo Verde): reflexões sobre um projecto de investigação e divulgação patrimonial André Teixeira / Jaylson Monteiro / Mariana Mateus / Nireide Tavares / Cristovão Fonseca / Gonçalo C. Lopes / Joana Bento Torres / Dúnia Pereira / André Bargão / Aurélie Mayer / Bruno Zélie / Carlos Lima / Christelle Chouzenoux / Inês Henriques / Inês Pinto Coelho / José Lima / Patrícia Carvalho / Tiago Silva

2103 A antiga fortificação de Quelba / Khor Kalba (E.A.U.). Resultados de quatro campanhas de escavações, problemáticas e perspectivas futuras Rui Carita / Rosa Varela Gomes / Mário Varela Gomes / Kamyar Kamyad

2123 Colónias para homens novos: arqueologia da colonização agrária fascista no noroeste ibérico Xurxo Ayán Vila / José Mạ . Señorán Martín 


\title{
O RECINTO DA FOLHA DO OURO 1 (SERPA) NO CONTEXTO DOS RECINTOS DE FOSSOS CALCOLÍTICOS ALENTEJANOS
}

\author{
António Carlos Valera ${ }^{1}$, Tiago do Pereiro ${ }^{2}$, Pedro Valério ${ }^{3}$, António M. Monge Soares ${ }^{4}$
}

\begin{abstract}
RESUMO
Apresentam-se os primeiros resultados dos trabalhos arqueológicos realizados no recinto de fossos calcolítico da Folha do Ouro 1 (Serpa, Beja). Identificado numa imagem satélite, o sítio integrou a investigação sobre este tipo de contextos desenvolvida pelo NIA-Era Arqueologia e foi submetido a prospecção geofísica por magnetometria e a recolha de materiais arqueológicos. É realizada a análise da colecção de materiais recolhidos, da referenciação cronológica que permitem, da implantação topográfica e das características arquitectónicas observadas no magnetograma obtido. O sítio é integrado no contexto regional, através da sua comparação com as características já conhecidas para outros recintos de fossos alentejanos.

Palavras-chave: Recintos de Fossos, Calcolítico, Sul de Portugal, Geofísica.
\end{abstract}

\begin{abstract}
This paper presents the first results of the archaeological work carried out in the Chalcolithic ditched enclosure of Folha do Ouro 1 (Serpa, Beja). The site was identified in an aerial image and integrated in the research developed by NIA-Era Arqueologia regarding this type of contexts and submitted to geophysics and surface prospection with collection of archaeological materials. Here, we address the assemblage of archaeological materials, the chronological scope of the site, its topographical location and architectonic characteristics observed in the magnetogram. The site is integrated in the regional context, comparing with the known characteristics of the Alentejo's ditched enclosures.
\end{abstract}

Keywords: Ditched Enclosures, Chalcolithic, South Portugal, Geophysics.

\section{INTRODUÇÃO}

O recinto de fossos da Folha do Ouro 1, situado no Alentejo, próximo da cidade de Serpa (Fig. 1), foi identificado numa imagem aérea de 2006 do Google Earth (Fig. 2:1) no âmbito de uma linha de investigação desenvolvida pelo Núcleo de Investigação Arqueológica da Era Arqueologia orientada para a detecção e caraterização dos recintos de fossos pré-históricos em Portugal (Valera, Becker 2011). Esta identificação e a respectiva imagem foram dadas a conhecer em 2013, no I Congresso de Arqueologia da AAP (Valera, Pereiro 2013, Fig. 4: 9). Mais recentemente, foi igualmente publicada uma nova imagem aérea (Fig. 2: 2) em que o conjunto de recintos surge com melhor definição (Valera, Pereiro 2019). Ainda assim, o sítio viria a ser afectado pela construção de um pivot de rega instalado perto do seu centro, fazendo com que uma parte dos recintos fosse cortada pela vala de implantação da tubagem de alimentação do referido pivot. Assim, juntando o interesse científico em obter a planimetria do sítio e informações sobre a sua cronologia à necessidade de avaliar a afectação sofrida e definir adequada-

\footnotetext{
1. Era Arqueologia / ICArEHB-Universidade do Algarve; antoniovalera@era-arqueologia.pt

2. Era Arqueologia; tiagopereiro@era-arqueologia.pt

3. Centro de Ciências e Tecnologias Nucleares (C2TN), Departamento de Engenharia e Ciências Núcleares, Instituto Superior Técnico, Universidade de Lisboa; pvalerio@ctn.tecnico.ulisboa.pt

4. Centro de Ciências e Tecnologias Nucleares (C2TN), Departamento de Engenharia e Ciências Núcleares, Instituto Superior Técnico, Universidade de Lisboa; amsoares@ctn.tecnico.ulisboa.pt
} 
mente o perímetro do recinto com vista à sua salvaguarda numa futura revisão do PDM de Serpa, foi realizada uma campanha de prospecções de superfície e de geofísica, a qual decorreu no final de Outubro de $2019^{5}$. São os resultados desses trabalhos e da análise dos materiais arqueológicos recolhidos à superfície que agora se publicam, juntamente com uma primeira interpretação da arquitectura do sítio e do seu enquadramento no contexto dos recintos de fossos alentejanos.

\section{LOCALIZAÇÃO E ENQUADRAMENTO GEOMORFOLÓGICO}

Administrativamente, o recinto de fossos da Folha do Ouro 1 localiza-se na união de freguesias de Salvador e Sta. Maria do concelho de Serpa, distrito de Beja. O centro do sítio situa-se a cerca de $625 \mathrm{~m}$ para ESE do marco geodésico com o mesmo nome (Folha do Ouro), e a $900 \mathrm{~m}$ a NO do Monte das Oliveiras, apresentando as seguintes coordenadas: $37^{\circ} 55^{\prime} 54.38^{\prime \prime} \mathrm{N}, 7^{\circ} 32^{\prime} 26.03^{\prime \prime} \mathrm{O}$, a uma cota de $220 \mathrm{~m}$ (Fig. 1). (Figura 1 e 2)

Em termos topográficos, o sítio localiza-se no topo aplanado de uma suave elevação, sobranceira ao vale pouco encaixado do Barranco da Morgadinha, integrando o extremo Este da elevação de cota mais alta onde se localiza o marco geodésico da Folha do Ouro, com uma cota de $227 \mathrm{~m}$ (Fig. 1). Assim, a sua visibilidade é restrita para Oeste, mas também para Sul, onde é limitada pelas cotas mais altas do interflúvio onde passa a estrada Serpa - Ficalho, a $1000 \mathrm{~m}$ do centro sítio. Para Norte a visibilidade é igualmente limitada por elevações de cotas ligeiramente mais altas, prolongando-se ao longo do corredor estabelecido pelo vale do Barranco da Morgadinha, que é igualmente a área visualmente abrangida para Este. $\mathrm{Ou}$ seja, embora se localize numa elevação, a visibilidade sobre a paisagem envolvente é relativamente restrita a áreas próximas do sítio, exercendo-se essencialmente sobre o vale que a percorre pelo lado Este. Em termos geológicos, o local apresenta um substrato integrado no Complexo gabro-diorítico de Cuba, o qual é composto por gabros, dioritos, quartzo-dioritos e granófiros, e que faz parte do Maciço de Beja (Carta Geológica de Portugal, 1:200ooo, fl.8).

5. A equipa de trabalho de campo foi constituída por António Carlos Valera, Tiago do Pereiro, Nelson Almeida e Ana Catarina Basílio.

\section{PROSPECÇÃO GEOFÍSICA, MAGNETOGRAMA E INTERPRETAÇÃO ARQUITECTÓNICA}

\subsection{Metodologia}

A prospecção geofísica foi realizada com recurso ao magnetómetro Bartington 6o1/2, com dois sensores de $1 \mathrm{~m}$ de comprimento separados por $1 \mathrm{~m}$. Cada um contém dois sensores verticais (axis fluxgate magnetometers) no topo e na base, fazendo com que os detectores localizados no topo rejeitem a larga escala do magnetismo atmosférico e isolem pequenas leituras causadas pelas anomalias arqueológicas, podendo detectar anomalias de o,1 nt (nanotesla), considerando-se que o campo magnético terrestre normalmente apresenta leituras de $40.000 \mathrm{nt}$ (o,4 gauss), que podem variar durante o dia. Este equipamento permite detectar anomalias até cerca de 3 $\mathrm{m}$ de profundidade (a média é $1 \mathrm{~m}$ ). A recolha dos dados teve por base uma grelha georreferenciada, com quadrados de $30 \times 30 \mathrm{~m}^{2}$. Estes quadrados foram divididos em 30 linhas de prospecção percorridas em modo zig-zag, permitindo a recolha de medidas a cada $0,125 \mathrm{~m}$ com espaçamento entre linhas de 0,5 $\mathrm{m}$. Os dados obtidos foram processados com software Geoplot 4.o.

\subsection{O magnetograma e a sua interpretação}

A quadrícula da geofísica foi implantada de modo a abranger a totalidade do recinto perceptível nas imagens aéreas, onde se observavam quatro fossos genericamente concêntricos. Assim, foi prospectada nesta primeira abordagem uma área total de $45,900 \mathrm{~m}^{2}$ (correspondendo a 51 quadrados de 30x3om). Contudo, o complexo de recintos revelar-se-ia maior, com mais dois fossos concêntricos exteriores, os quais não foram totalmente abrangidos pela prospecção a Norte, a Oeste e a Sul. O magnetograma obtido revela, assim, um conjunto de recintos circulares ou sub-circulares concêntricos, apresentando seis fossos. Os dois recintos interiores são constituídos por um único fosso cada, enquanto que os recintos mais exteriores são definidos por duplo fosso (Fig. 2: 3).

\subsubsection{O Recinto 1}

O Recinto 1, o mais interior, apresenta um diâmetro de $30 \mathrm{~m}$ e uma área aproximada de $707 \mathrm{~m}^{2}$. O fosso que o define (Fosso 1) tem sete lóbulos que se desenvolvem a partir uns dos outros (tipo A na tipologia 
proposta em Valera 2012) e uma interrupção alinhada com outras nos restantes recintos, formando um alinhamento de entradas orientado a $114^{\circ}$. Pelo exterior, arrancando junto ao lado Sul da entrada, existe um segmento semicircular que lhe passa pela frente e se vai reunir ao lóbulo localizado mais a Norte, formando um longo corredor onde parece existir mais que uma interrupção. Trata-se de um condicionamento do acesso ao recinto interior muito semelhante ao que se observa no recinto interior de Xancra (Valera, Becker 2011) (Figura 3: 2). No interior deste recinto central são visíveis inúmeras anomalias que corresponderão a estruturas negativas de tipo fossa, contabilizando-se um número aproximado de 30.

\subsubsection{O Recinto 2}

O Recinto 2 é igualmente definido por um único fosso (Fosso 2), envolve o primeiro de forma concêntrica, distando dele cerca de $20 \mathrm{~m}$ em média. O seu diâmetro é de aproximadamente $80 \mathrm{~m}$, apresentando uma área de $5027 \mathrm{~m}^{2}$ (incluindo a área do Recinto 1). O fosso apresenta um total de 14 lóbulos também tendencialmente de tipo A e duas entradas: uma no alinhamento orientado a $114^{\circ}$ e outra num novo alinhamento de entradas com os recintos exteriores (mas não com o interior) orientado a $22^{2} 2^{\circ}$. Ambas as entradas apresentam os característicos segmentos curvos frontais, que em ambos os casos parecem arrancar do lado direita da entrada (vista a partir do exterior). No espaço interior compreendido entre o Fosso 1 e o Fosso 2 é observável um numeroso conjunto de anomalias correspondendo a estruturas negativas, que apresentam uma maior concentração no quadrante Sudeste. Foi contabilizado um número mínimo de 67.

\subsubsection{O Recinto 3}

O Recinto 3 é definido por dois fossos sub-circulres concêntricos, sendo o interior lobulado (Fosso 3 ) e o exterior linear (Fosso 4). A largura do corredor entre estes dois fossos ronda em média $10 \mathrm{~m}$, sendo que o diâmetro do recinto definido pelo Fosso 3 varia entre $140 / 150 \mathrm{~m}$ e o do recinto definido pelo Fosso 4 varia entre $160 / 180 \mathrm{~m}$. A área interior ao Fosso 3 é aproximadamente de $16513 \mathrm{~m}^{2}$ (abrangendo a dos recintos mais interiores) e a área definida pelo Fosso 4 é cerca de $22698 \mathrm{~m}^{2}$ (incluindo as anteriores). O fosso interior (Fosso 3 ) apresenta 26 lóbulos espaçados e ligados por pequenos troços lineares, corres- pondendo ao tipo B (Valera 2012). Ambos os fossos apresentam duas entradas, integradas nos alinhamentos a $114^{\circ}$ e $232^{\circ}$. Todas apresentam um troço curvo frontal pelo exterior, sendo que a entrada SE do Fosso 4 é mais ampla que as restantes (atingindo cerca de $20 \mathrm{~m}$ de abertura, enquanto todas as entradas descritas anteriormente representam aberturas entre 2 e $4 \mathrm{~m}$ ). O espaço entre os Fossos 2 e 3 (separados em termos médios por cerca de $30 \mathrm{~m}$ ) apresenta em todo o seu perímetro uma grande concentração de anomalias correspondentes a estruturas negativas, algumas delas alongadas, totalizando um número superior a duas centenas). Já no corredor entre o Fosso 3 e o Fosso 4 o número destas anomalias (cerca de quatro dezenas) é mais reduzido, mesmo tendo em conta a proporção das áreas. Tal reforça a ideia de que estes dois fossos são construções contemporâneas e que definem um recinto que é ocupado/utilizado sobretudo no espaço definido pelo fosso mais interior, sendo o corredor entre ambos essencialmente de circulação. (Figura 3)

\subsubsection{O Recinto 4}

O Recinto 4, o mais exterior, é igualmente definido por dois fossos, sendo o interior também lobulado (Fosso 5) e o exterior linear (Fosso 6). Como referido, apenas a parte Este destes fossos e alguns pequenos troços do lado Oeste estão abrangidos pelo magnetograma, pelo que a sua caracterização fica, para já, mais limitada. Assim, não é possível ter a contabilização global dos lóbulos do Fosso 5 (no magnetograma são visíveis pelo menos 17), os quais também se apresentam espaçados e ligados por troços lineares, enquadrando-se no tipo B. O corredor entre os dois fossos apresenta dimensões idênticas (cerca de $10 \mathrm{~m}$ de largura) às registadas ao espaço entre os Fossos 3 e 4, e tal como aquele apresenta um número muito reduzido de anomalias correspondentes a estruturas negativas. O cálculo dos diâmetros máximos e das áreas definidas por estes dois fossos apenas podem, de momento, ser estimadas. Assim, para o Fosso 5 estimam-se diâmetros entre 200/190 m, correspondendo a uma área aproximadamente de $29865 \mathrm{~m} 2$, e para o Fosso 6 diâmetros de $220 / 200 \mathrm{~m}$, com uma área aproximada de $34636 \mathrm{~m}^{2}$. No espaço interior, entre o Fosso 5 e o Fosso 4, existem igualmente inúmeras anomalias correspondentes a estruturas negativas. $O$ facto de este espaço não ter sido abrangido na totalidade pela prospecção geofísica impede uma aproximação ao número total 
destas anomalias. Ainda assim, foram contabilizadas mais de uma centena, com uma concentração de grandes estruturas no lado Norte (Figura 3: 6) e uma outra do lado Oeste. Na parte Sul, este espaço apresenta uma grande anomalia no magnetograma, a qual deverá ser de natureza geológica. Relativamente às entradas, estes dois recintos apresentam amplas aberturas "tracejadas" no alinhamento das entradas anteriores a $114^{\circ}$, que é o único alinhamento de entradas que percorre todos os fossos. Já no que respeita ao alinhamento de entradas a $23^{\circ}$, o Fosso 5 apresenta aí uma entrada, mas que parece não ser seguida no Fosso 6, ainda que tal observação não possa ser peremptória dadas as descontinuidades no magnetograma nesse ponto. Talvez ocorra aqui o mesmo que se regista no ponto diametralmente oposto $\left(53^{\circ}\right)$, com uma entrada ligeiramente desencontrada entre os dois fossos (Figura 3: 5). Mais nenhum dos recintos apresenta entradas com esta orientação. Estes são também os únicos fossos em que as entradas não revelam a existência de um troço curvo frontal pelo exterior.

Por último, há ainda que salientar a existências de algumas anomalias correspondentes a estruturas negativas no exterior do complexo de recintos. As áreas externas abrangidas pelo magnetograma são, contudo, residuais, pelo que não é ainda possível ter uma ideia adequada da densidade e dispersão destas estruturas no exterior.

\section{A COMPONENTE ARTEFACTUAL}

A componente artefactual reporta-se exclusivamente a material recolhido à superfície durante a realização da prospecção geofísica. As categorias artefactuais presentes são os elementos cerâmicos, a indústria lítica talhada e polida e um objecto metálico. Foram ainda recolhidos alguns escassos fragmentos de ossos inclassificáveis e um dente de Sus sp., assim como três fragmentos de concha: um de Pecten maximus, outro de Ruditapes decussatus e outro de Unio sp..

\subsection{A cerâmica}

Foram recolhidos 44 bordos e uma asa com perfuração vertical. No conjunto dos bordos, 39 permitiram reconstituição formal. Predominam os pratos (3 de bordo simples, 21 de bordo espessado e 1 carenado), seguidos das taças ( 9 abertas simples, I fechada e 1 carenada). Registaram-se, ainda, bordos de um esférico, de um recipiente tipo saco e de um recipiente de perfil em "S" (Figura 4: 1-18). Ainda em cerâmica, foi recolhido um fragmento erodido de "Ídolo de Cornos”, com parte da típica perfuração central.

\subsection{Indústria lítica talhada}

Os elementos de indústria lítica registados são em número reduzido. Em pedra talhada foram registados três segmentos de lâmina com retoque marginal (Fig. 4: 19-20), seis lascas e um seixo talhado (Fig. 5: 4), sendo a matéria prima predominante o chert, com uma lâmina em rocha ígnea, uma lasca em sílex e outra em quartzo. Ainda dentro da categoria de pedra talhada foram registados vários percutores esferóides em quartzo e granito/diorito, alguns deles simultaneamente usados como bigorna (Fig. 4: 22).

\subsection{Pedra Polida}

Relativamente a utensílios de pedra polida, foram recolhidos um machado de secção elipsoidal e de polimento abrangente, um fragmento de utensílio de pedra polida alongado de secção irregular e um esboço de utensílio de secção sub-trapezoidal (Fig. 5: 1-3). Recolheu-se igualmente um fragmento de xisto polido com orifício circular, correspondendo a um possível peso (Fig. 5: 5). Finalmente foram registados três fragmentos de dormentes de mó manual.

\subsection{Metal e análise arqueometalúrgica}

$\mathrm{O}$ artefacto em análise foi igualmente recolhido à superfície quando se procedia à prospecção geofísica no sítio da Folha do Ouro 1. A sua superfície encontrava-se coberta por concreções acastanhadas muito aderentes formando uma camada homogénea, com uma ou outra pequena área esverdeada ou avermelhada, resultantes estas da eliminação das referidas concreções devido, porventura, a deslocações que a peça sofreu durante os trabalhos agrícolas. O peso do objecto $(244,3 \mathrm{~g})$, bem como as marcas esverdeadas e avermelhadas, permitiram desde logo identificar o artefacto como sendo manufacturado a partir de um metal de base cobre. A cor acastanhada da superfície resultaria da incorporação de partículas do solo nos produtos de corrosão do metal, especialmente na camada mais superficial, como se verificou após a sua limpeza mecânica. Trata-se de um artefacto com uma patina verde, de forma tabular, prismática, de cantos arredondados, com um peso de 239,9g (após a limpeza superficial) e com cerca de $11 \mathrm{~cm}$ de comprimento por 3,6 $\mathrm{cm}$ de largura e uma espessura máxima de 1,2 $\mathrm{cm}$ (Figura 5: 6). 
A interpretação para a funcionalidade deste artefacto, que nos parece mais consentânea com a forma que apresenta, é a de se tratar de um lingote. Uma das faces maiores é convexa, enquanto a face oposta é plana. Uma observação cuidada permite verificar que, nesta, os bordos se elevam muito ligeiramente (algumas décimas de milímetro). Estes factos indiciam que a forma do objecto em causa resulta do vazamento do metal num molde rectangular, de fundo ligeiramente côncavo, muito provavelmente um daqueles artefactos cerâmicos ligados à metalurgia calcolítica vulgares no sul do país e que, habitualmente, são interpretados como cadinhos. Ao possível lingote falta, aparentemente, um fragmento num dos cantos, mas o aspecto da "fractura", algo boleada, e a inexistência de quaisquer vestígios de corte levam a colocar a hipótese de essa perda de massa metálica resultar apenas de um qualquer acidente durante a operação de vazamento.

A identificação do metal constituinte do artefacto foi realizada por espectrometria de fluorescência de raios $\mathrm{X}$, dispersiva de energias, utilizando um espectrómetro portátil Bruker Si Titan equipado com um tubo de raios $\mathrm{X}$ com ânodo de ródio, um detector SSD e um colimador para a análise de áreas de dimensão reduzida. $\mathrm{O}$ artefacto foi previamente preparado para análise através da remoção dos produtos de corrosão superficial numa área com cerca de $5 \times 5 \mathrm{~mm}^{2}$ (Valério et al. 2019). Em seguida foram efectuadas diversas análises para identificar possíveis heterogeneidades composicionais, encontrando-se na tabela seguinte os respectivos resultados. (Tabela 1).

Verifica-se, por conseguinte, que se trata de um cobre muito puro em que apenas o arsénio e o ferro foram detectados como impurezas. Composições deste tipo são típicas do Calcolítico do Sul de Portugal, cuja metalurgia se caracteriza por artefactos de cobre com teores variáveis de arsénio (Valério et al. 2016). A composição do possível lingote da Folha do Ouro 1 é também muito semelhante às dos artefactos que têm sido interpretados como lingotes com esta cronologia, como são os casos do exemplar de Leceia (Cardoso, Braz Fernandes 1995) e o de Porto Mourão (Soares et al. 1996). Deverá, no entanto, notar-se que esta composição por si só não prova a possível funcionalidade que temos atribuído ao artefacto. A análise micro-estrutural que pensamos realizar num futuro próximo é que poderá produzir os indícios que, conjugados com a forma do artefac- to e os resultados da análise composicional, justifiquem de uma forma incontroversa a funcionalidade que até agora lhe temos atribuído. Será também imperioso, nesse caso, proceder a uma análise de isótopos de $\mathrm{Pb}$ para tentar determinar a proveniência do cobre utilizado na sua manufactura. (Figura 4 e 5 )

\section{BREVE APONTAMENTO SOBRE \\ A FOLHA DO OURO I NO CONTEXTO DOS RECINTOS DE FOSSOS CALCOLÍTICOS LOBULADOS PADRONIZADOS DO ALENTEJO}

Quer pela cultura material recolhida à superfície, quer pelas características arquitectónicas evidenciadas pelo magnetograma, o recinto de fossos da Folha do Ouro 1 é enquadrável no Calcolítico do Sudoeste. Naturalmente as suas temporalidades e cronologias mais precisas são, de momento, difíceis de estabelecer sem o recurso a trabalhos de arqueologia intrusivos. Contudo, numa análise meramente prospectiva, algumas observações podem ser feitas tendo por base as suas características arquitectónicas e a sua integração no que, de momento, se conhece para os recintos de fossos da bacia do médio Guadiana.

A morfologia lobulada regular dos dois recintos centrais, assim como as suas dimensões, número de lóbulos, tendência circular e concentricidade (sempre que existe mais que um fosso), aproxima-os dos recintos do Outeiro Alto 2, de Borralhos, de Xancra, da Horta do Albardão 3 ou de Santa Vitória. Há hoje já um número suficiente deste tipo de recintos, com plantas integrais ou quase integralmente conhecidas, para se poder começar a falar de uma certa padronização arquitectónica típica da bacia do Guadiana. Este padrão manifesta-se quer em termos de dimensões aproximadas, seja dos recintos seja das distâncias internas entre fossos, quer no número, forma e na própria dimensão dos lóbulos (recente trabalho de aplicação da análise de morfometria geométrica aos lóbulos de vários destes recintos verificou esta regularidade (Valera et al. 2019), para qual já havia um primeiro ensaio interpretativo - (Valera 2020) quer ainda na predominância de entradas alinhadas, em vários casos a eventos astronómicos (Valera 2013).

No caso da Folha do Ouro 1, a este padrão regular lobulado (de Tipo A - Valera 2012) evidenciado pelos dois recintos interiores, junta-se um outro até agora ausente neste tipo de recintos de fossos: o fosso du- 
plo, com o fosso interno lobulado de Tipo B (lóbulos espaçados com um segmento recto intermédio) e um fosso linear externo. Até ao momento, esta situação só era conhecida no grande recinto da Salvada (Valera, Pereiro 2015) e em Moreiros 2 (Valera et al. 2013) (Fig. 6). O recinto da Salvada apresenta um duplo fosso onde o fosso interior é um lobulado regular (mas de Tipo A) e o fosso externo é linear. Este é também o único grande recinto de fossos conhecido (com cerca de 18 ha) que apresenta um fosso com lobulado regular). Em Moreiros 2 o duplo fosso é também exterior (numa aparente segunda fase construtiva), apresentando igualmente um fosso interno lobulado regular de tipo B e um fosso externo linear, assim como também entradas desencontradas como a registada no duplo fosso externo da Folha do Ouro. A principal diferença que se regista no duplo fosso de Moreiros é a sua tendência poligonal, com ângulos suaves e mais ou menos abertos, caso único nos recintos de fossos portugueses (e que apenas encontra paralelo nas plantas dos recintos muralhados de S. Pedro (Mataloto 2010) e Porto das Carretas (Soares, Silva 2010). Outros recintos apresentam igualmente duplos fossos que, correspondendo sempre aos mais exteriores, são nestes casos ambos lineares (Fig. 6). É essa a situação que se observa nos fossos externos dos Perdigões (Márquez Romero et al. 2011) e nos fossos externos de Montoito (Valera et al. 2015). Curiosamente, a equidistância entre os fossos que compõem estes fossos duplos é aproximadamente a mesma nos vários recintos em que ocorrem, entre 10 a 15 metros, sugerindo também aqui uma padronização. (Figura 6)

O mesmo se poderá dizer relativamente à estruturação das entradas, as quais, dentro de uma certa variabilidade (Valera, Pereiro 2020), apresentam soluções que se vão repetindo, reforçando a ideia da existência de modelos gerais que vão sendo seguidos de forma mais ou menos aproximada. É o caso dos troços alongados em frente das entradas de alguns recintos centrais, formando uma espécie de corredor de acesso lateral (casos de Xancra e Folha do Ouro 1) ou dos segmentos curvos frontais às entradas (casos da Folha do Ouro 1, Montoito, Perdigões, Xancra, Borralhos ou Monte da Contenda).

De facto, conforme se vão obtendo mais plantas completas ou tendencialmente completas destes recintos, o que em grande medida se fica a dever à utilização da geofísica como estratégia indispensável de abordagem a contextos e que dificilmente poderiam ser conseguidas por meio de intervenções arqueológicas intrusivas, mais vai emergindo um modelo que, com algumas variantes, parece marcar uma forma regionalizada de desenhar recintos de fossos.

Esta padronização poderá ser ainda maior se pensarmos que muitos dos desenhos observados traduzem temporalidades diferentes. Ou seja, alguns destes recintos terão tido vidas mais longas que outros, o que se poderá traduzir na maior complexidade e investimento arquitectónico que uns apresentam relativamente a outros. Se o Outeiro Alto 2 apresenta um único fosso, as escavações recentemente realizadas em Santa Vitória revelam que também aí terá existido inicialmente apenas um fosso e só depois se terá construído o segundo. O mesmo poderá ter acontecido em Xancra, Folha do Ouro 1 ou Borralhos, o que só a escavação arqueológica poderá esclarecer, mas que a proximidade da morfologia e tamanho dos respectivos pequenos recintos centrais sugere. Em Borralhos, contudo, a própria geofísica permite perceber que existe um processo construtivo diferido no tempo (Valera, Pereiro 2020). Por outras palavras, boa parte da variabilidade que se observa nestes recintos lobulados regulares, por exemplo ao nível do número de fossos e das dimensões, poderá ficar a dever-se aos diferentes tempos de vida e de construção que cada um apresenta.

Outra questão que emerge da padronização destes desenhos arquitectónicos, da sua regularidade surpreendente como acontece com a Folha do Ouro 1, é o facto de ela nos ser perceptível essencialmente na sua representação gráfica ou fotográfica em plantas, magnetogramas ou imagens aéreas. O facto de em Santa Vitória, para se perceber um pouco melhor a planta no local, ter sido construída uma torre é exemplificativo da dificuldade de leitura destes desenhos e da sua regularidade ao nível do terreno. Por outro lado, no caso deste tipo de recintos lobulares padronizados já escavados (Santa Vitória, Outeiro Alto 2 e Horta do Albardão 3) não se registaram quaisquer evidências de delimitações físicas verticais (taludes ou paliçadas) a acompanhar os fossos. O que os dados disponíveis vão sugerindo é a delimitação de espaços por fossos, mas sem outros elementos de constrangimento ou de grande impacto visual. À semelhança dos geoglifos de Nasca, os espaços desenhados e os trajectos delineados podem ser percorridos ao nível do terreno, mas só são perceptíveis na sua integralidade a partir de cima, como se tivessem sido feitos para ser vistos por outras en- 
tidades (Valera 2020). A ser assim, a monumentalidade que emerge nestes recintos tem mais a ver com o trabalho envolvido, com a forma como se organiza e estrutura o espaço com referenciais de ordem cosmológica e com as actividades que ocorreriam no seu interior (Valera 2013; 2020), e menos com o impacto visual das suas arquitecturas, tanto mais que existem evidências, por inúmeras vezes sublinhadas, de estes recintos funcionarem com os fossos a serem intencionalmente preenchidos, parcialmente reabertos ou construídos de forma segmentada e sequencial. Esta é mais uma linha de pensamento e investigação que este tipo de recintos, em que a Folha do Ouro 1 se integra, suscitam.

Outra é a proximidade espacial entre alguns deles que vai emergindo no mapa do Alentejo. No caso concreto da parte sul da margem esquerda portuguesa do Guadiana é, neste sentido, importante sublinhar a proximidade da Folha do Ouro 1 ao recinto do Outeiro Alto 2 (situado a 10,5 km a NO), ao recinto de Borralhos (situado a 9,5 $\mathrm{km}$ a ENE), ao grande complexo de recintos da Herdade da Corte (a $15,3 \mathrm{~km}$ a NE) e ao sítio de São Brás 3 (localizado 7 $\mathrm{km}$ a SO) e cuja implantação sugere poder tratar-se igualmente de um recinto de fossos. Naturalmente, a proximidade espacial não implica proximidade temporal, e sem boas sequências cronológicas (que na região e para estes contextos, só verdadeiramente existem para os Perdigões, com mais de uma centena de datações) não é possível estabelecer, de forma segura, uma contemporaneidade entre sítios que nos obrigue pensar os significados dessas vizinhanças. Poderão não ter todos funcionado ao mesmo tempo, tendo temporalidades diferentes. Poderão ter tido ocupações periódicas alternadas em diferentes momentos, tendo uma utilização genericamente contemporânea, mas não simultânea. Ou poderão ter estado envolvidos em estratégias de emulação social e comportamentos miméticos (Valera, 2019). Os dados actualmente disponíveis suscitam muitas questões e permitem ainda poucas respostas, mas a proximidade espacial e arquitectónica destes recintos no actual concelho de Serpa é, seguramente, outro dos problemas que obriga a repensar alguns velhos axiomas (tal como a proximidade entre os grandes recintos da Salvada e Monte das Cabeceiras 2, no outro lado do Guadiana, já vinha obrigando - Valera, Pereiro 2015; Valera 2019).

\section{CONCLUINDO}

Com a prospecção geofísica do recinto da Folha do Ouro 1, a investigação desenvolvida pelo NIA-ERA (por vezes em parceria com outras instituições) sobre os recintos de fossos pré-históricos no interior alentejano produziu o décimo terceiro magnetograma deste tipo de sítios. Este trabalho, associado a outros realizados no âmbito de projectos de investigação ou arqueologia de salvamento, evidencia a relevância, até há duas décadas insuspeita, que este fenómeno tem na região. Permite avançar na sua caracterização, definição de tendências e complexidades arquitectónicas, temporalidades e na formulação de linhas de inquérito que só podem ser desenvolvidas a partir de plantas integrais ou quase integrais. Muitas das questões levantadas precisam, contudo, de um aumento da amostragem, o qual tem essencialmente decorrido do empenhamento do NIA-ERA e das parcerias que pontualmente tem conseguido criar (como aconteceu com o município de Serpa nos levantamentos de Borralhos e Folha do Ouro 1). Outros recintos, que poderão reforçar linhas interpretativas ou sugerir novas orientações da investigação, continuam à espera que se possa realizar o seu levantamento. Situação urgente, já que noutros, igualmente importantes, este trabalho já está inviabilizado pela agricultura intensiva de olival e amendoal. Neste contexto, cada novo magnetograma que se obtém e publica, para além do que traz ao processo de investigação, é verdadeiro serviço público.

\section{AGRADECIMENTOS}

Agradece-se o apoio logístico do Município de Serpa na realização do trabalho de campo. A caracterização arqueometalúrgica foi efectuada no âmbito do Projecto UID/Multi/o4349/2019 financiado pela Fundação para a Ciência e a Tecnologia.

\section{BIBLIOGRAFIA}

CARDOSO, J.L. e BRAZ FERNANDES, F. (1995) - Estudo arqueometalúrgico de um lingote de cobre de Leceia (Oeiras). Estudos Arqueológicos de Oeiras. 5. pp. 153-164.

MÁRQUEZ ROMERO, J.E.; VALERA, A.C.; BECKER, H.; JIMÉNEZ, V. e SUÀREZ, J. (2011) - El Complexo Arqueológico dos Perdigões (Reguengos de Monsaraz, Portugal). Prospecciones Geofísicas - Campaña 2008-09. Trabajos de Prehistoria. 68-1. pp. 175-186. 
MATALOTO, R. (2010) - O 3.ำ4.ำ milénio a.C. no povoado de São Pedro (Redondo, Alentejo Central): fortificação e povoamento na planície centro alentejana. In: Gonçalves, V., Sousa, A.C. (Eds) Transformação e mudança no centro e sul de Portugal: o $4^{0}$ e o $3^{\circ}$ milénios a.n.e.. Cascais. CMC. pp. 263-295.

SOARES, A.M.M.; ARAÚJO, M.F.; ALVES, L. e FERRAZ, M.T. (1996) - Vestígios metalúrgicos em contextos do Calcolítico e da Idade do Bronze no Sul de Portugal. Miscellanea em Homenagem ao Professor Bairrão Oleiro. Lisboa. Colibri. pp. 553-579.

SOARES, J. e SILVA, C.T. (2010) - Campaniforme do Porto das Carretas (médio Guadiana). A procura de novos quadros de referência. In: Gonçalves, V. Sousa, A.C., (Eds) Transformação e mudança no centro e sul de Portugal: o $4^{\circ}$ e o $3^{\underline{0}}$ milénios a.n.e.. Cascais, CMC, pp. 225-261.

VALERA, A.C. (2012) - Fossos sinuosos na Pré-História Recente do Sul de Portugal: ensaio de análise crítica. Actas do V Encontro de Arqueologia do Sudoeste Peninsular. Município de Almodôvar, pp. 25-38.

VALERA, A.C. (2013) - Breve apontamento sobre a dimensão cosmogónica dos recintos de fossos da Pré-História Recente no Interior Alentejano. Cadernos do Endovélico, 1. Colibri/CMA. pp. 51-63.

VALERA, A.C. (2019) - Landscapes of complexityin Southern Portugal during de $4^{\text {th }}$ and $3^{\text {rd }}$ millennium BC. In: J. Müller, M. Hintz, M. Wunderlich (Eds.) Megaliths, Societies, Landscapes. Early monumentality and social differentiation in Neolithic Europe. Frühe Monumentalität und soziale Differenzierung. 18. Vol. 3/3. Bonn. Verlag Dr. Rudolf Habelt GmbH. pp. 1039-1054.

VALERA, A.C. (2020) - Ephemeral and Cosmological Monumentality: the 'strange' ditched enclosures of Chalcolithic South Portugal. In: A.B. Gebaue; L. Sorensen, A. Teather and A.C. Valera (Eds.) Monumentalizing life in the Neolithic: Narratives of continuity and change. Oxford. Oxbow, pp. 239-250.

VALERA, A.C., BECKER, H. (2011) - Cosmologia e recintos de fossos da Pré-História Recente: resultados da prospecção geofísica em Xancra (Cuba, Beja). Apontamentos de Arqueologia e Património. 7. Lisboa. NIA-ERA Arqueologia. pp. 23-32.
VALERA, A.C.; BECKER, H. e BOAVENTURA, R. (2013) - Moreiros 2 (Arronches, Portalegre): geofísica e cronologia dos recintos interiores. Apontamentos de Arqueologia e Património. 9. Lisboa. Nia-Era. pp. 37-46.

VALERA, A.C.; BECKER, H. e COSTA, C. (2015) - Os recintos de fossos Pré-Históricos de Monte da Contenda (Arronches) e Montoito 2 (Redondo). Estudos Arqueológicos de Oeiras. 21. CMO. pp. 195-216.

VALERA, A.C., GODINHO, R. e PEREIRO, T. DO (2019) - Cosmologia e padronização dos recintos de fossos lobulados: uma abordagem morfogeométrica. Comunicação no colóquio Os recintos da Pré-História Recente: avanços no estudo das suas arquitecturas e espacialidades. Lisboa. Museu Arqueológico do Carmo (Novembro de 2019).

VALERA, A.C. e PEREIRO, T. DO (2013) - Novos recintos de fossos no sul de Portugal: o Google Earth como ferramenta de prospecção sistemática. Actas do I congresso da Associação dos Arqueólogos Portugueses. Lisboa. AAP. pp. 345-350.

VALERA, A.C. e PEREIRO, T. DO (2015) - Os recintos de fossos da Salvada e Monte das Cabeceiras 2 (Beja, Portugal). Actas do VII Encontro de Arqueologia Peninsular. Aroche-Serpa.pp. 316-327.

VALERA, A.C. e PEREIRO, T. DO (2019) - A geofísica e salvaguarda do património arqueológico em meio rural. Vantagens e quando utilizar: o caso dos recintos de fossos. Scientia Antiquitatis. 1. Évora. pp. 193-205.

VALERA, A.C. e PEREIRO, T. DO (2020) - O recinto de fossos pré-Histórico de Borralhos (Serpa): aproximação à sua arquitectura através da prospecção geofísica. Apontamentos de Arqueologia e Património. 14. pp. 17-28.

VALÉRIO, P.; SOARES, A.M.M. e ARAÚJO, M.F. (2016) - An overview of Chalcolithic copper metallurgy from Southern Portugal. MENGA. Revista de Prehistoria de Andalucía.7.pp. 31-50.

VALÉRIO, P.; SOARES, J.; ARAÚJO, M.F.; ALVES, L.C. e TAVARES DA SILVA, C. (2019) - The composition of São Brás copper hoard in relation to the Bell Beaker metallurgy in southwestern Iberian Peninsula. Archaeometry. 61/2. 392-405.

\begin{tabular}{lccc}
\hline Análise & $\mathrm{Cu}(\%)$ & As (\%) & Fe (\%) \\
\hline 1 & 99,8 & 0,12 & n.d. \\
\hline 2 & 99,8 & 0,15 & 0,09 \\
\hline 3 & 99,7 & 0,16 & 0,10 \\
\hline Média & 99,8 & 0,13 & 0,03 \\
\hline
\end{tabular}

Tabela 1 - Composição do possível lingote da Folha do Ouro I (n.d.: não detectado). 

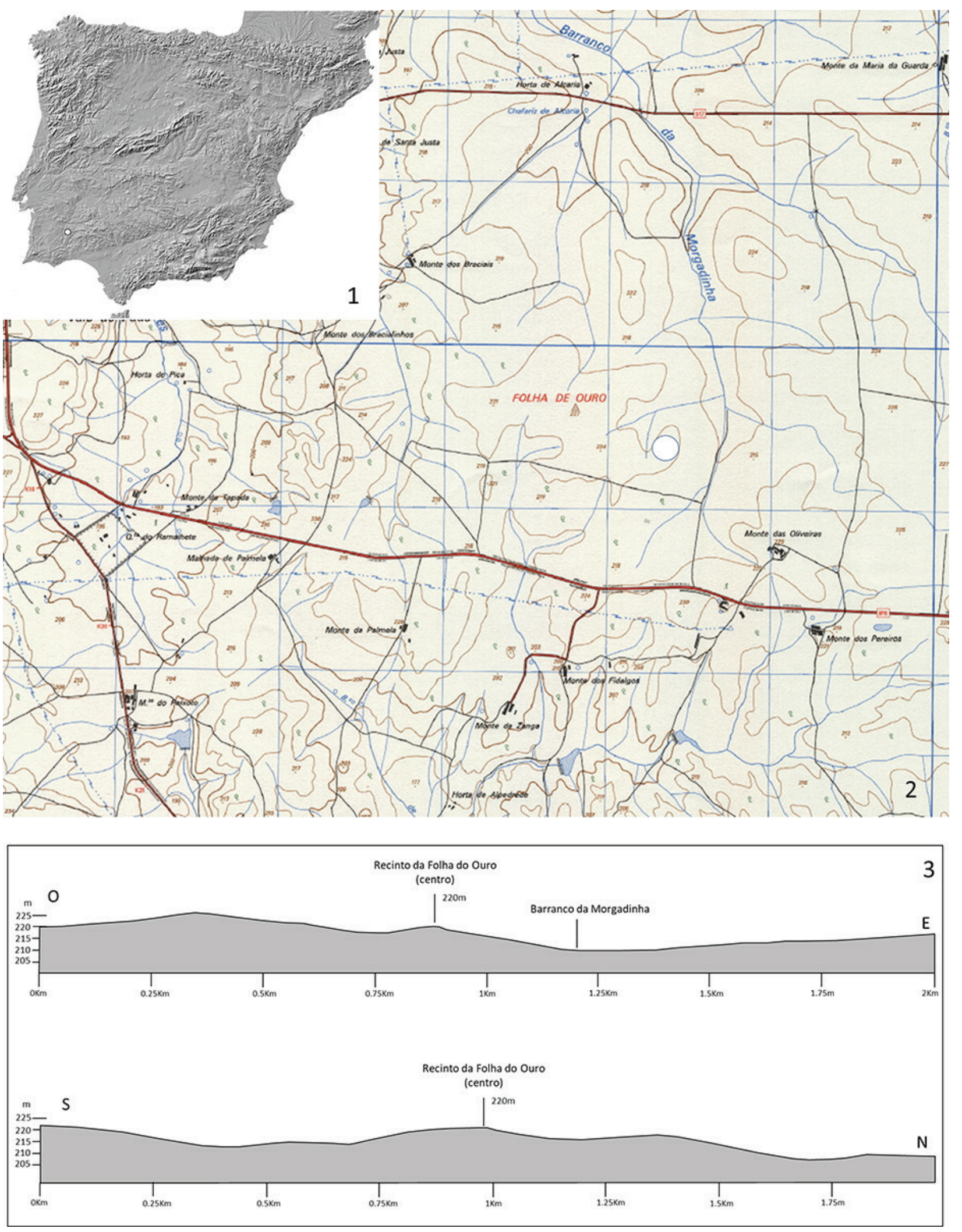

Figura 1 - Localização do recinto da Folha do Ouro 1 na Península Ibérica (1), na C.M.P., 1:250oo, fl. 533 (2) em dois perfis topográficos perpendiculares (3). 


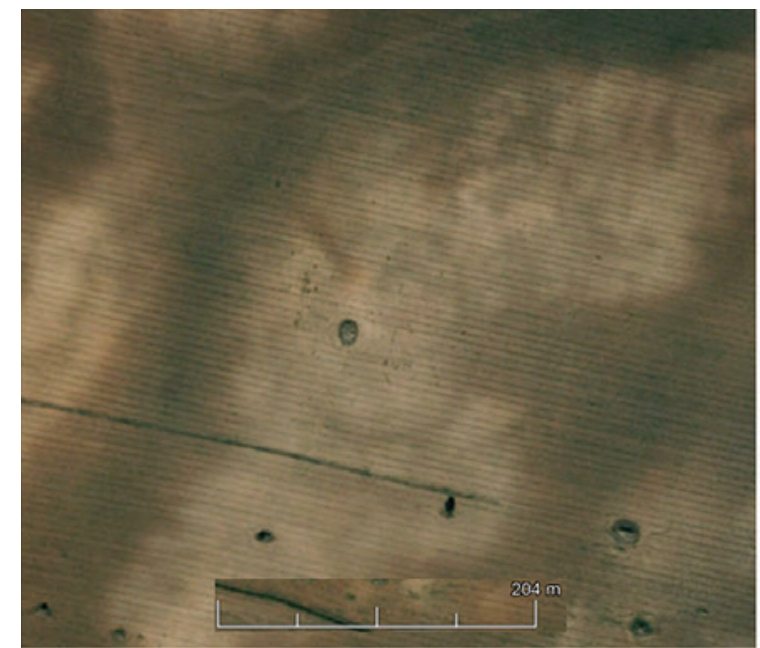

1

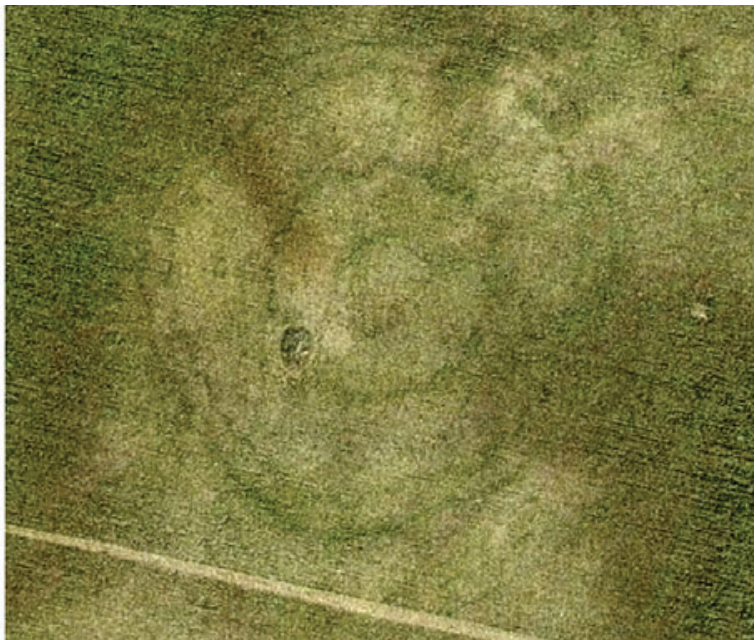

2

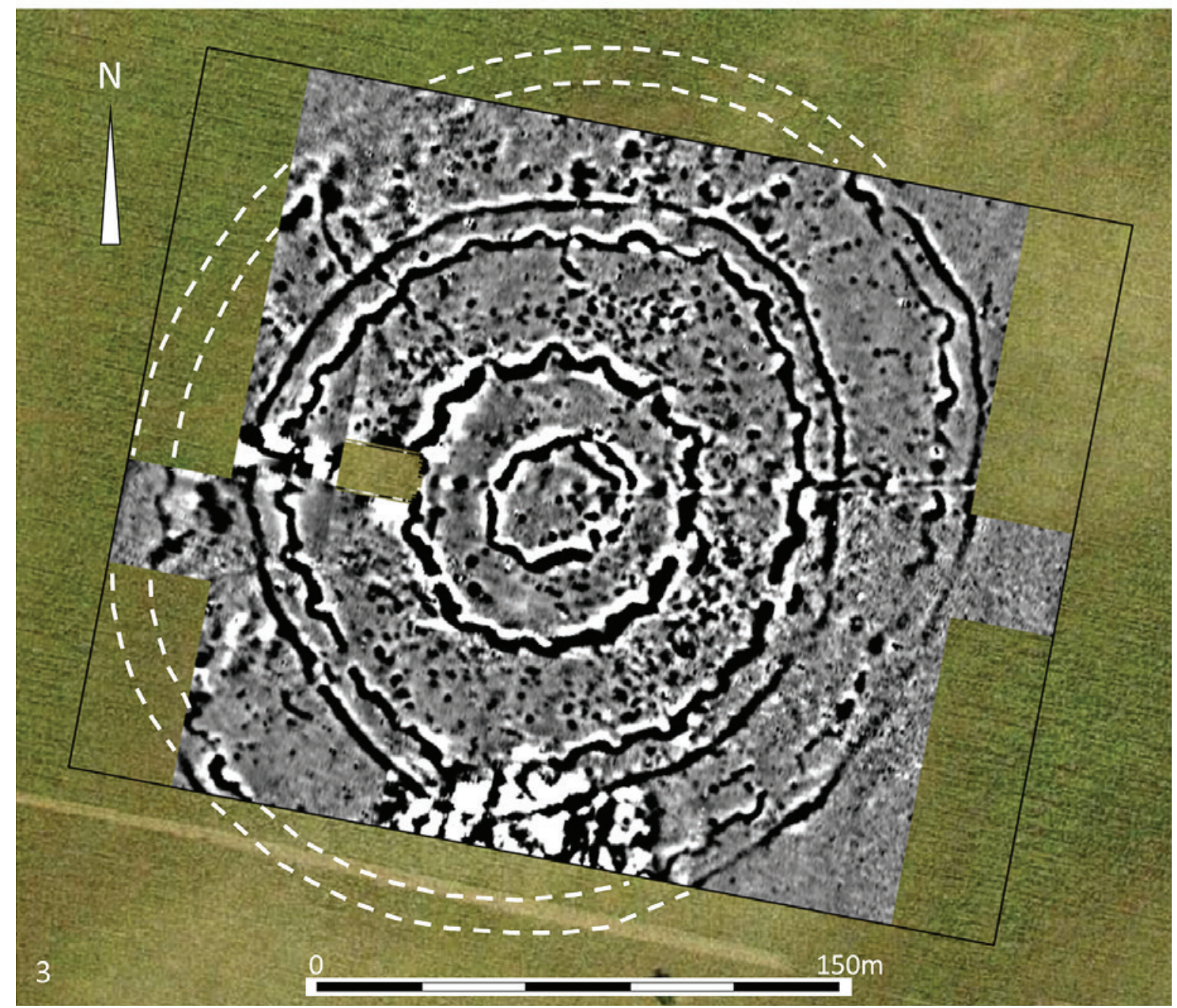

Figura 2 - (1) Folha do Ouro 1 em imagem aérea de 2006 do Google Earth; (2) Folha do Ouro em imagem aérea de 2018 (3) Magnetograma das prospecções geofísicas realizadas em 2019 na Folha do Ouro 1. 

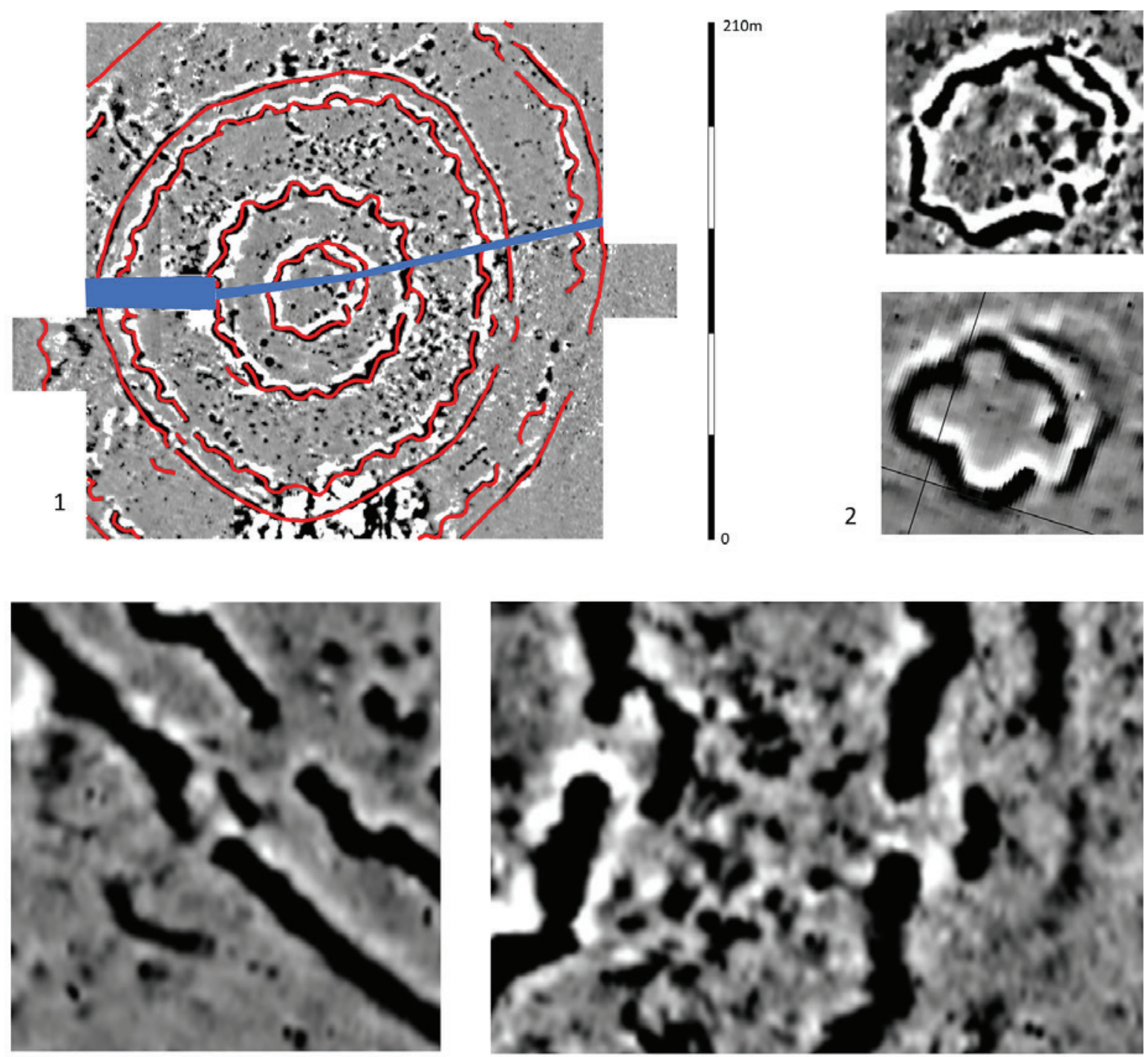

3

4

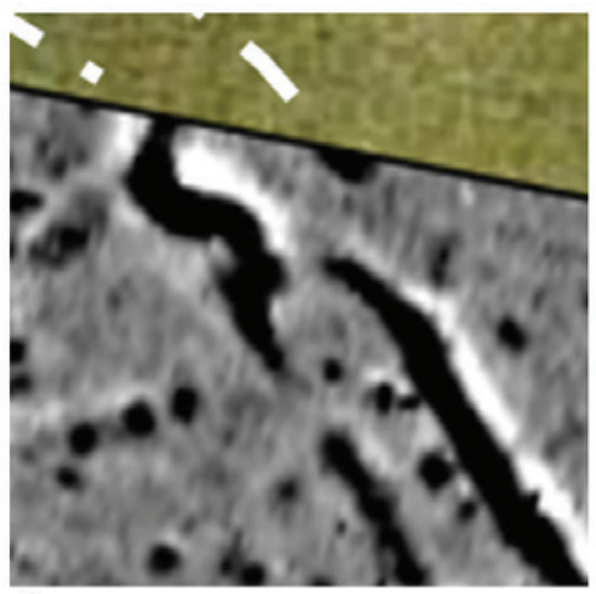

5

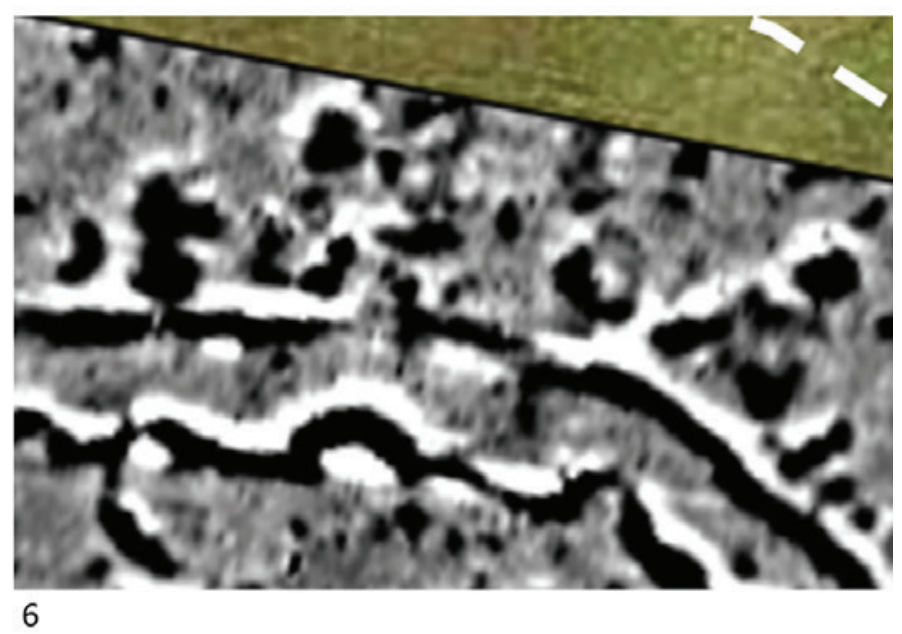

Figura 3 - (1) Magnetograma anotado, com desenho dos fossos e marcação da conduta e espaço ocupado pelo pivot; (2) comparação do recinto interior da Folha do Ouro 1 (em cima) com o recinto interior de Xancra (em baixo); (3) detalhe da entradas dos fossos 3 e 4 no alinhamento a $22^{2} 2^{\circ}$; (4) detalhe das entradas dos fossos 2 , 3 e 4 no alinhamento a $114^{\circ}$; (5) detalhe da entrada Noroeste nos fossos 5 e 6; (6) detalhe da concentração de grandes estruturas negativas na área Norte, entre os fossos 4 e 5 . 

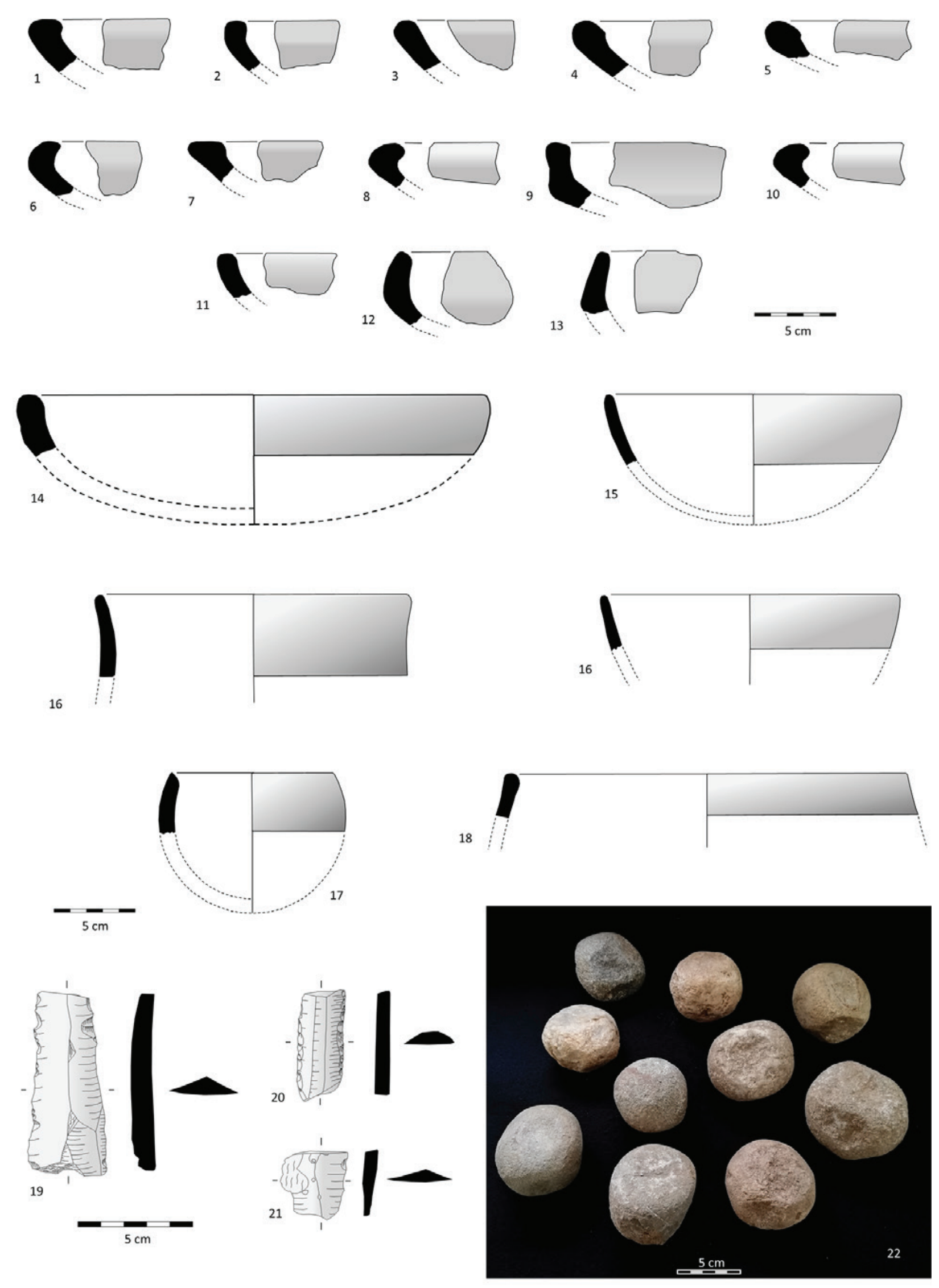

Figura 4- Materiais cerâmicos e líticos recolhidos à superfície. 

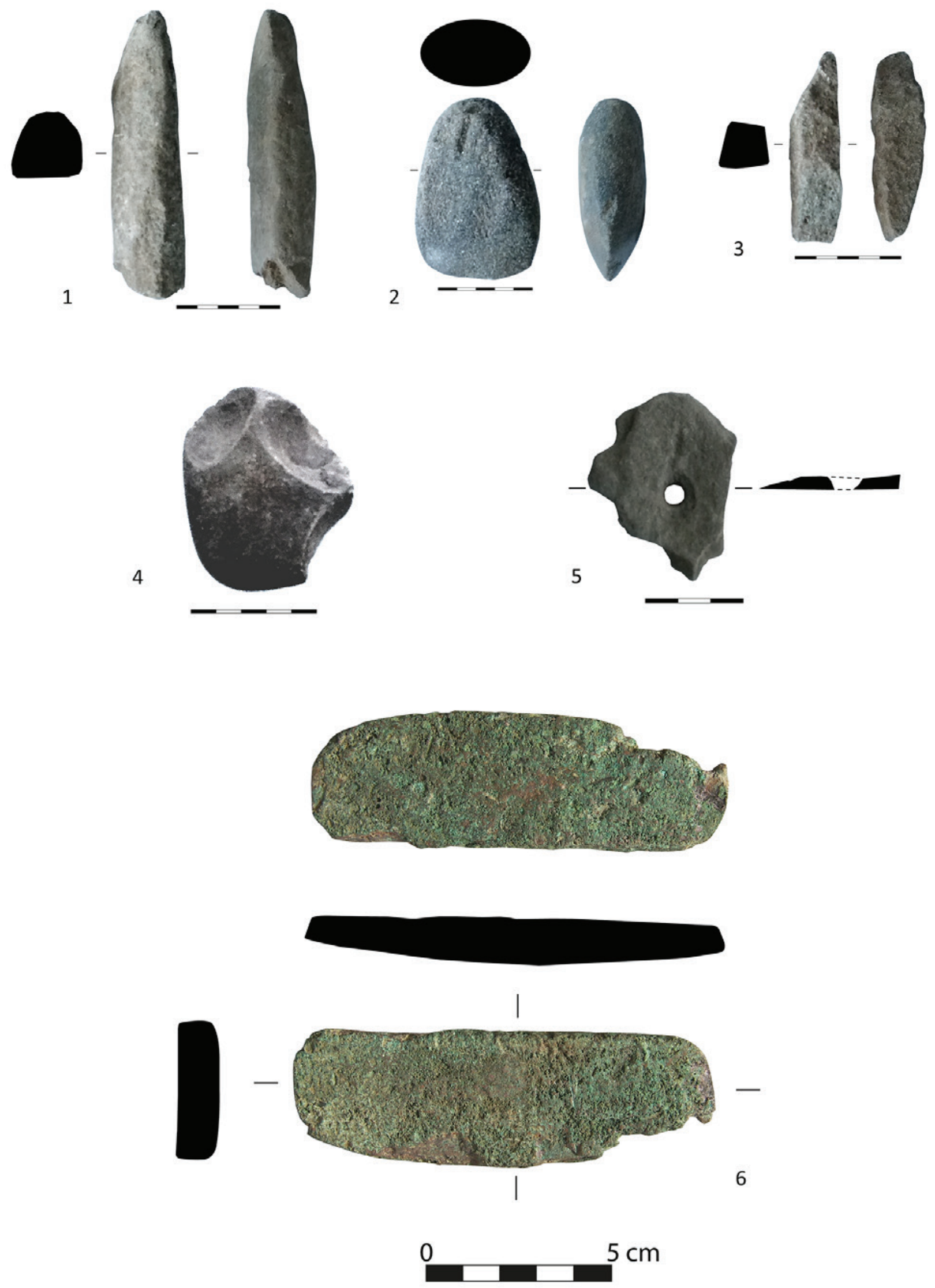

Figura 5 - Materiais líticos e metálicos recolhidos à superfície. 1 - 3 pedra polida; 4 Seixo talhado; 5 Placa de xisto perfurada; 6. Possível lingote de cobre. 


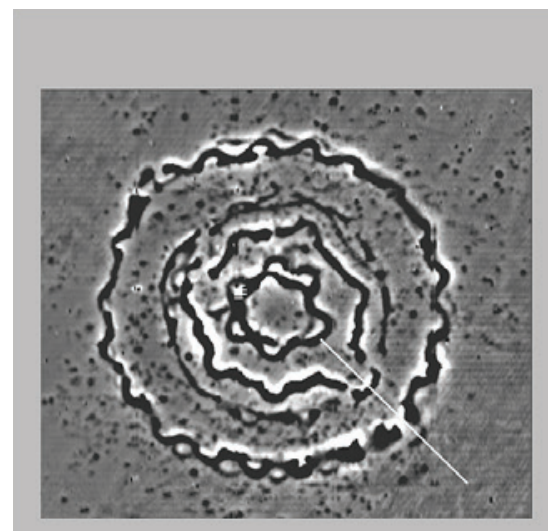

1
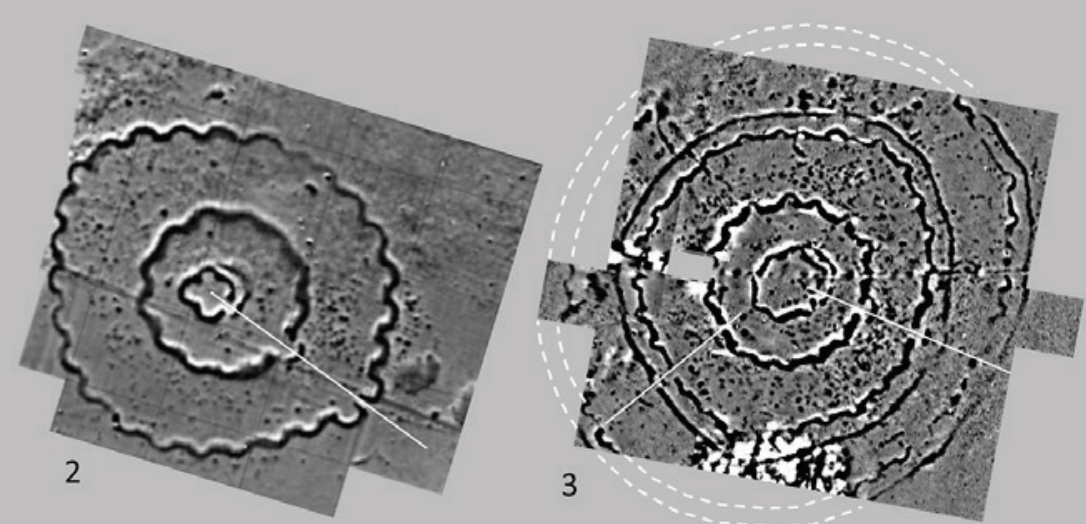

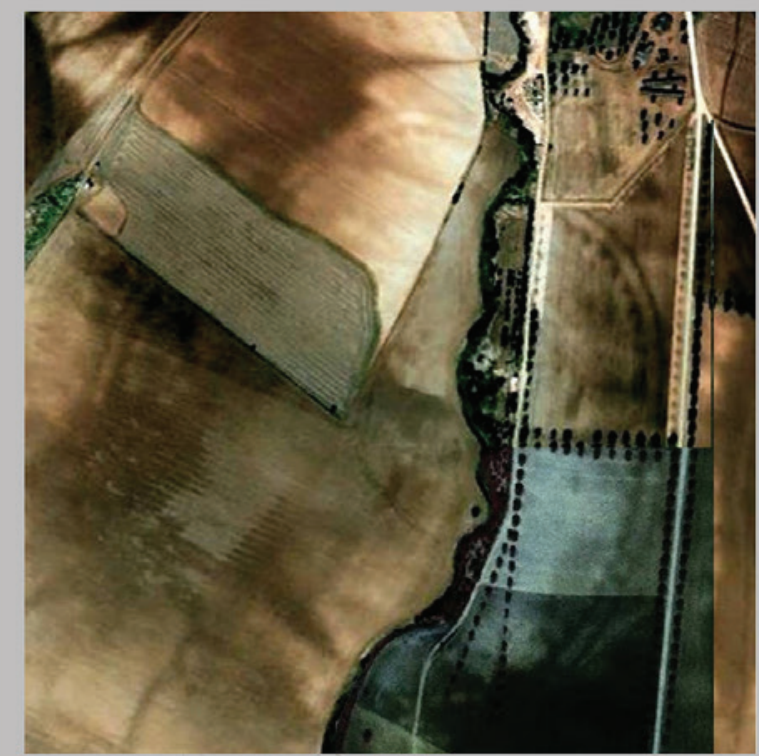

4

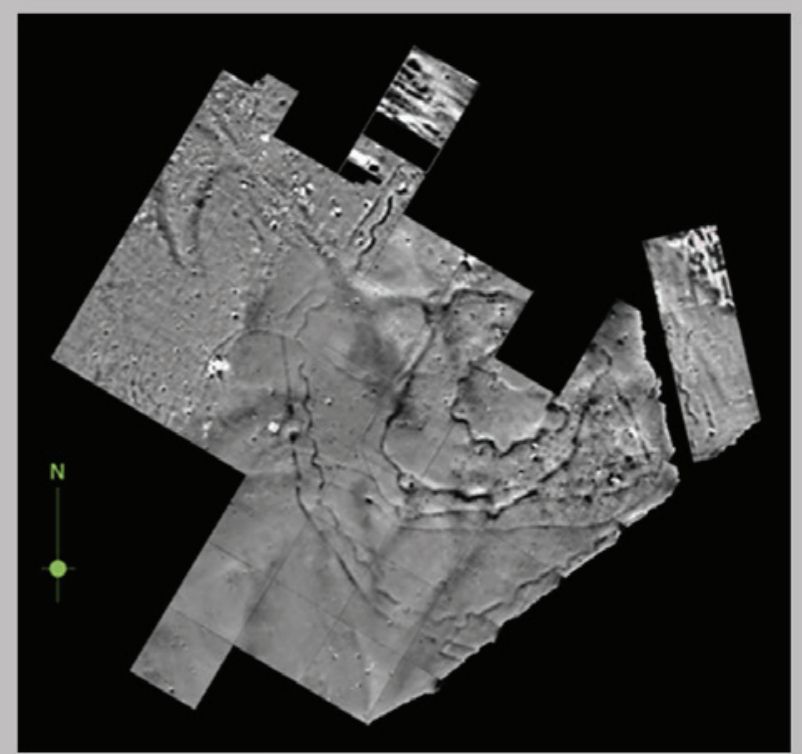

5
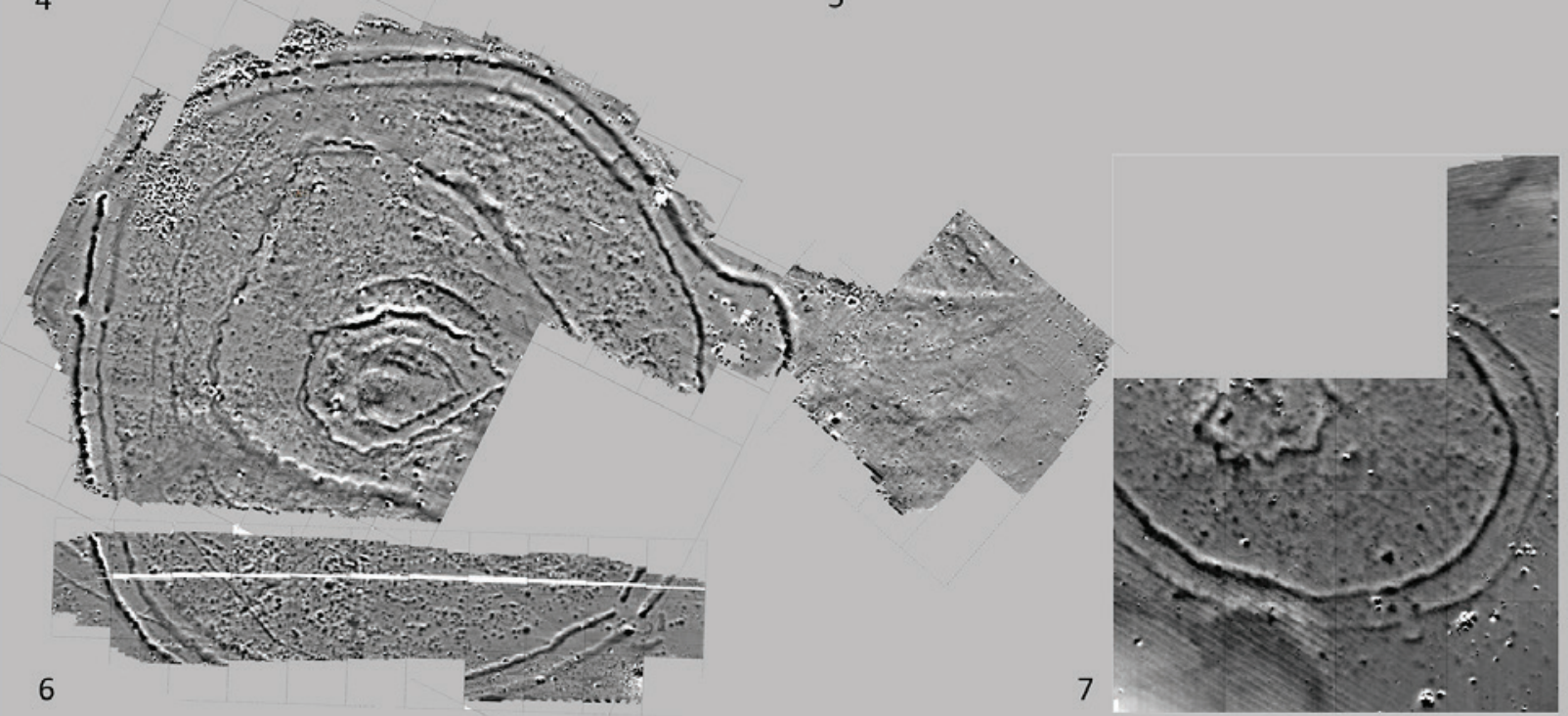

Figura 6 - Recintos de fossos lobulados padronizados ou com duplo fosso linear ou lobulado/linear. (1) Xancra; (2) Xancra; (3) Folha do Ouro 1; (4) Salvada; (5) Moreiros 2; (6) Perdigões; 7. Montoito. 



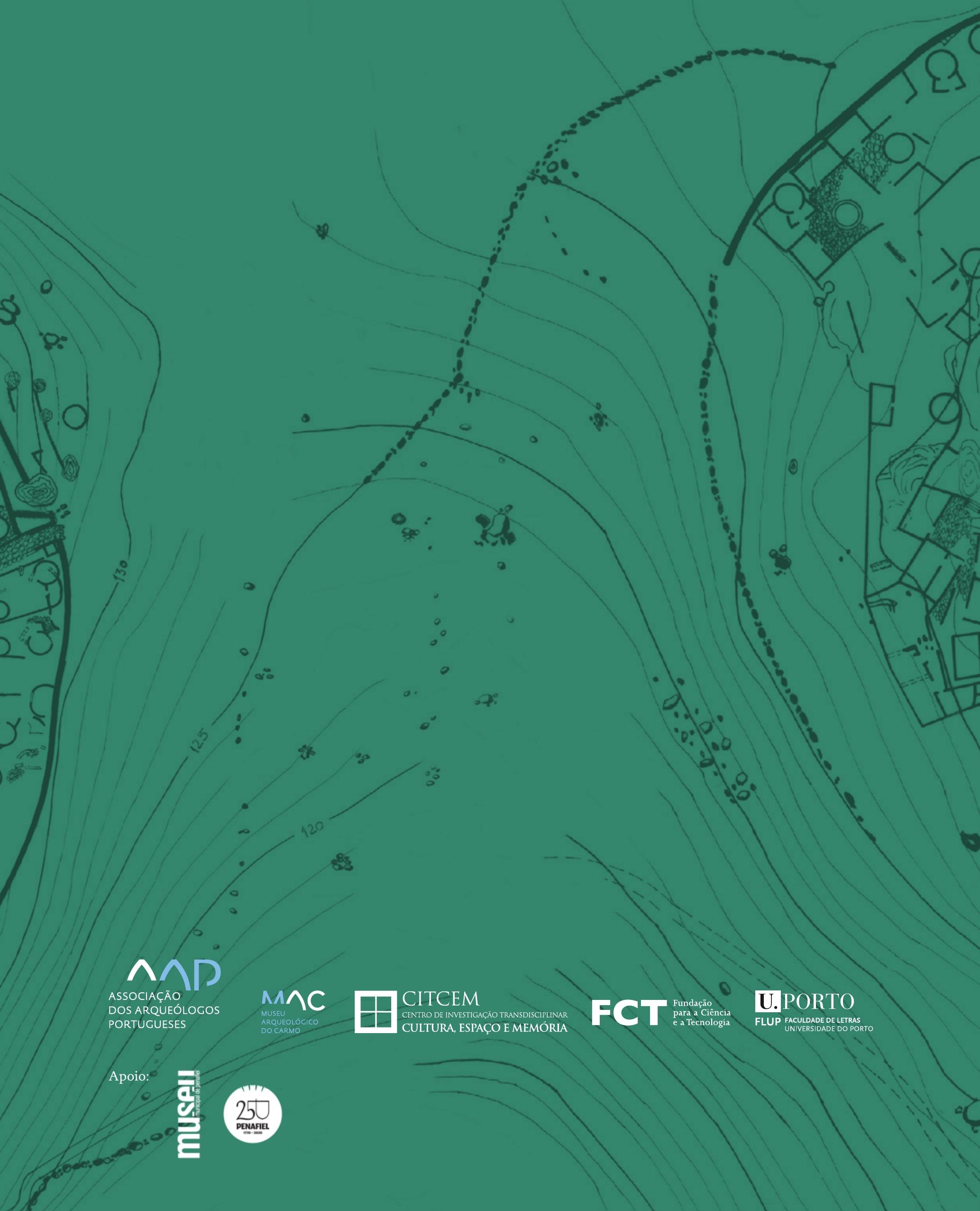

